\title{
The Impact of Tropical Cyclones in Premonsoonal Season on Local Convection over the Al-Hajar Mountains in Oman during 2007-2018
}

\author{
Salma Al-Zadjali ${ }^{D},{ }^{1}$ Zamzam Al-Rawahi ${ }^{D},{ }^{2}$ and Hamid Al-Brashdi ${ }^{3}{ }^{3}$ \\ ${ }^{1}$ Institute for Risk and Disaster Reduction, University College London, London, UK \\ ${ }^{2}$ Department of Research \& Development, Civil Aviation Authority, Muscat, Oman \\ ${ }^{3}$ Department of Strategic Planning, Civil Aviation Authority, Muscat, Oman \\ Correspondence should be addressed to Salma Al-Zadjali; lal.zadjali.19@ucl.ac.uk
}

Received 5 January 2021; Revised 11 March 2021; Accepted 23 March 2021; Published 12 April 2021

Academic Editor: Federico Porcù

Copyright (c) 2021 Salma Al-Zadjali et al. This is an open access article distributed under the Creative Commons Attribution License, which permits unrestricted use, distribution, and reproduction in any medium, provided the original work is properly cited.

\begin{abstract}
The tropical cyclones (TCs) and convective storms have a significant impact on triggering widespread flooding in vulnerable areas. However, it is not clear whether the TCs stimulate the convective precipitation over the Al-Hajar Mountains in Oman or suppress it although it had been shown in many studies that TCs suppress the local convection development. This study aims to test the applicability of the hypothesis that the TCs suppress the convection over mountainous to the Al-Hajar Mountains. In order to test the hypothesis of tropical cyclones' impact on local convection development over the Al-Hajar Mountains, this study considers three different cases during the premonsoon season between 2007 and 2018. The results revealed that weak local convection is reported over the Al-Hajar Mountains during the presence of the cyclones in the Arabian Sea and during the period of their direct impacts. The rainfall in these cases was mainly from stratiform clouds. Therefore, the impact of TCs on the convective suppression over the mountains is applicable to the Al-Hajar Mountains. This study will provide decision-makers and policy creators with knowledge as to whether the Al-Hajar Mountains are susceptible and vulnerable to the risk of torrential downpour, flash flooding, and thunderstorms as what is believed to be.
\end{abstract}

\section{Introduction}

Tropical cyclones (TCs) and cyclonic storms (CSs) encountered from the Arabian Sea are a semiannual threat for Omani coasts during the premonsoonal (May-June) and postmonsoonal (October-November) seasons [1]. Based on India Meteorological Department (IMD) [2] statistics, the total number of TCs in the Arabian Sea recorded during the period from 1891 to 2019 reached 81. This number is relatively small compared to the total number which formed in the Bay of Bengal during the same period which reached 239 cases. However, the associated destruction caused is extensive since a most of the population of Oman live in the low-lying coastal areas [3]. Figure 1 presents the monthly frequency of TCs in the Arabian Sea between 1981 and 2019.
Despite the large number of TCs which forms in the Indian Ocean, only a few of them advance to the Arabian Sea [4]. TCs generally form over southeast and central regions of the Arabian Sea in May and October through December and in east-central regions in June. Some of the TCs that originate in the Bay of Bengal travel across the peninsula, weaken and emerge into the Arabian Sea as low-pressure systems, and may again intensify into CSs. These systems initiate as a depression in the sea with maximum sustained surface wind range between 17 knots and 27 knots. CSs occur when sustained wind speed falls between 34 knots and 63 knots. Based on the criteria adopted by the Directorate General of Meteorology in Oman (DGMET), the tropical system is classified as "TC" when its maximum sustained wind speed exceeds 63 knots. Of the total disturbances in the 
Arabian Sea, 35\% may intensify to CSs and 7\% into TCs. In contrast to the Regional Specialized Meteorological Centre (RSMC) in New Delhi, India, the Sultanate of Oman uses a different scale which is recommended by World Meteorological Organization (WMO) for maximum sustained wind assessment of a TC and that of a 10-minute average at the height of $10 \mathrm{~m}$. The classification of TCs in the Saffir Simpson scale for the wind speed and pressure fall within the center is divided into five different categories shown in Table 1.

Based on the atmospheric models under the IPCC A1B scenarios where the balance among all the energy sources and improvement are applied [5], the TCs centers in the north Indian Ocean (NIO) are more likely to shift westward toward the Arabian Sea during the postmonsoonal season. Accordingly, Omani and Yemeni coasts are more likely to be threatened with the tropical system in the following years that already been witnessed since 2014 . On the other hand, Evan et al. [6] showed that more intense TCs events in the Arabian Sea occurred during the premonsoonal seasons over the past 30 years.

The dominant source of rainfall in Oman is from the convective rain [7]. The high insolation of solar heat in summer months and the synoptic and mesoscale features interaction with the orographic forcing mechanism by the Al-Hajar Mountains are the essential factors in convection initiation over the mountains [8-12]. At a local level, Al-Brashdi [7] discussed the formation of heat low in the Empty Quarter in Arabian Peninsula and explained how its position relative to the mountains could control the wind regime and thus the intensity of local activity in the mountains. The convection intensity is classified into three categories: nonactive, active, and very active based on the cloud top temperature (CTT) represented by satellite images and the spatial coverage of the developed cells simultaneously [7, 13-15]. Nonactive convection refers to when no significant convection is observed, that is, when CTT $\geq 233$. In active convection, only isolated cells form with $213<$ CTT $<233$, whereas severe convective clouds form within multicells with associated CCT $<=213$.

Very active convections are more likely to occur when the thermal heat deepens south of the mountains where the prevailing air mass flow becomes southeast from the Arabian Sea causing the convergence of the bulk of moisture flux towards the mountains [7]. The outcome of latter research by Al-Brashdi [7] supports the analysis of earlier study by AlMaskari et al. [16] on the relation between the thermal low and wind pattern on the local convection in the Al-Hajar Mountains. This can be explained by the strong convergent flow from the Arabian Sea towards the thermal flow arising from the steep temperature gradient between the land and the sea represented by the Empty Quarter desert and the Arabian Sea, respectively.

In the summer season, particularly during July and August, the oscillation of Intertropical Convergence Zone (ITCZ) and its movement towards the Al-Hajar Mountains stimulates the intensity of the convection over the mountains. The moisture transport from the

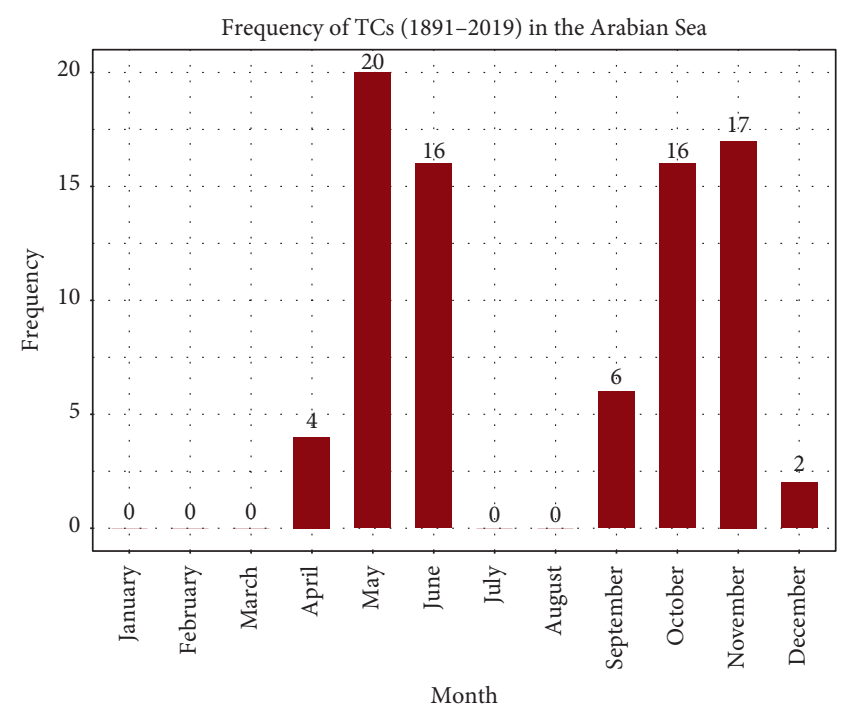

FIgURE 1: Monthly frequency of TCs in the Arabian Sea during 1891-2019 (source: IMD).

Table 1: The classification of TCs in the Saffir Simpson scale according to the central pressure and the wind speed.

\begin{tabular}{lcc}
\hline Category & Pressure $(\mathrm{mb})$ & Associated wind speed knots $(\mathrm{Km} / \mathrm{h})$ \\
\hline 1 & $\geq 980$ & $64-82(119-153)$ \\
2 & $979-965$ & $83-95(154-177)$ \\
3 & $964-945$ & $96-112(178-208)$ \\
4 & $944-920$ & $113-136(209-251)$ \\
5 & $<920$ & $>136(>251)$ \\
\hline
\end{tabular}

monsoonal wind, the latent heat release from the condensation along the ITCZ, and the depth of temperature inversion in the lower and middle troposphere have positive feedback on very active convection over the AlHajar Mountains [7,17].

In the present study, the precipitation over the Al-Hajar Mountains in Oman between 2007 and 2018 during the influence of TCs in the premonsoonal seasons is researched. The primary aim of this research is to test the hypothesis that the influence of TCs on convective suppression over the mountainous is applicable to the Al-Hajar Mountains. In the vicinity of the mountains, the precipitation is controlled by orographic lifting rather than the tropical system-accompanied rain band [18].

Thus, this research helps to understand the impact of TCs on local convection activity over the Al-Hajar Mountains and to identify the potential of convective storm development during the TCs. Besides, it is set out to be a baseline for reducing the vulnerability in mapping the least vulnerable areas to thunderstorms and flooding in Oman during the TCs as the mountain topography and poor infrastructure invite the susceptibility of natural hazards to disaster.

This study is carried out 24 hours before the approach of the TCs and during its direct impact either by landfall or by crossing the coast of Oman. To assess this, the stability of the atmosphere, the prevailing wind, the moisture profile, and rainfall distribution are analyzed in addition to satellite data. 


\section{Materials and Methods}

2.1. Study Area. The topography of Oman is heterogeneous, including mountains, deserts, and coastal areas. The AlHajar Mountains, which is about $700 \mathrm{~km}$ length with the highest altitude of $3076 \mathrm{~m}$ in Jabal Shams, play a major role in convective rainfall during the summer season (May-September).

This study is focused on three TCs in the Arabian Sea formed during 2007-2018 and their effect on the Al-Hajar Mountains in the north of Oman. The Al-Hajar Mountains extend from the extreme north of the Sultanate in the vicinity of the Arabian Gulf from the west and the Sea of Oman from the east to the southeastern coasts of Oman in boundary with the Arabian Sea in Ras Al-Hadd. In total, three water vapor sources surround the mountains which are the Arabian Gulf at the northwest, the Sea of Oman at the northeast, and the Arabian Sea in connection with the Indian Ocean at the southeast. Thus, the south-westerly monsoonal wind from Somali-Jet [19] has a great influence on the formation of tropical systems as well as the development of the convective storms in the Al-Hajar Mountains. Additionally, the exposure of Al-Hajar Mountains to the sea breeze from three ocean basins throughout the year [20] leads to the advection of sufficient moisture in the atmosphere, especially at low levels.

\subsection{Data}

2.2.1. Best Track. The best track of six hourly trajectory data of the three TCs in this study is obtained from the United States Navy's Joint Typhoon Warning Center (JTWC). It consists of parameters of the best track of the six hourly records for the position, the intensity, and sea level pressure (SLP) of the TCs. It also includes the estimated central pressure (ECP) $(\mathrm{hPa})$ and maximum sustained wind speed (knots). The time format on all of the tracking map is represented as (yyyymmddhh) based on UTC.

2.2.2. Satellite Data. Meteosat Second Generation (MSG) Spinning Enhanced Visible and Infrared Imager (SEVIRI) 15 min scan data were used as input for brightness temperature difference (BTD) that is between WV $6.2 \mu \mathrm{m}$ and IR10.8 $\mu \mathrm{m}$, to identify any active convection development over the mountain during the selected cases. The cloud type and its microphysical properties were identified by using day cloud microphysics DCMP RGB ( $\mathrm{R}=\mathrm{VIS} 0.8, \mathrm{G}=\mathrm{IR} 3.9, \mathrm{~B}=\mathrm{IR} 10.8)$ product. The moisture distribution in the middle and lower layers of the troposphere is indicated by using water vapour channel (WV7.3 $\mu \mathrm{m}$ ) due to its sensitivity to the water vapor concentration mainly between $700 \mathrm{hPa}$ and $500 \mathrm{hPa}$. The satellite data processing was carried out through MCIDAS-V software. Table 2 depicts the specification of SEVIRI channels used in this study.

The near real-time daily accumulated precipitation data from the Tropical Rainfall Measuring Mission (TRMM) Multi-Satellite Precipitation Analysis with 0.25-
TABLE 2: Specifications of SEVIRI channels: spectral range and spatial resolution.

\begin{tabular}{lccc}
\hline $\begin{array}{l}\text { Channel } \\
\text { no. }\end{array}$ & $\begin{array}{c}\text { Channel } \\
\text { name }\end{array}$ & $\begin{array}{c}\text { Spectral range } \\
(\mu \mathrm{m})\end{array}$ & $\begin{array}{c}\text { Spatial resolution } \\
(\mathrm{Km})\end{array}$ \\
\hline 2 & Vis0.8 & $0.56-0.71$ & 3 \\
4 & IR3.9 & $3.48-4.36$ & 3 \\
5 & WV6.2 & $5.35-7.15$ & 3 \\
6 & WV7.3 & $6.85-7.85$ & 3 \\
8 & IR9.7 & $9.38-11.80$ & 3 \\
9 & IR10.8 & $9.80-11.80$ & 3 \\
\hline
\end{tabular}

degree $\times 0.25$-degree resolution are obtained from NASA Earth data (Goddard Earth Sciences Data and Information Services Center, 2016) [21].

2.2.3. Surface Observations. The observations of various meteorological variables temperature $(\mathrm{T})$, relative humidity (RH\%), precipitation, and wind direction (WD) are collected from meteorological weather stations of Directorate General of Meteorology (DGMET) in Oman. Rainfall and wind data were taken from several stations along the AlHajar Mountains. Table 3 shows the stations included in this study with their longitudes, latitudes, and amplitudes.

2.2.4. Upper Air Observations. The atmospheric profile was obtained from the radiosonde of Muscat International Airport (OOMS). This upper air station (lat: $23.614 \mathrm{~N}$ and lon: $58.258 \mathrm{E}$ ) is about $50 \mathrm{~km}$ away from the east of the AlHajar Mountains [7]. The sounding data were collected from the Atmospheric Science Department at Wyoming University in the USA. The data of 00UTC is considered in this paper.

2.2.5. Sea Surface Temperature (SST). NESDIS Global $100 \mathrm{~km}$ daily sea surface temperature (SST) $\left({ }^{\circ} \mathrm{C}\right)$ data is generated from NOAA/NESDIS Office of Satellite Data Processing and Distribution (1998). It is a composite grided image derived from $8 \mathrm{~km}$ global SST.

2.3. Methodology. The focus of this study is to analyze the convection activity when TCs exist in the Arabian Sea for the period from 2007 to May 2018 with a total number of three TCs formed during that period. The analyzed cases are for three major TCs which influenced Oman significantly by either approaching its coasts or by making landfall with indicated occurring period: TC "Gonu” (01-07 June 2007); TC "Phet" (31 May-07 June 2010), and TC "Mekunu" (21-27 May 2018).

The study period in this research is classified into two intervals, 24 hours before the system landfall and the direct influence of the system while its landfall. The best tracks are estimated by using the JTWC best track archive data to monitor the TCs intensity while their advancement towards Oman.

The collection of surface observations of precipitation, temperature $(\mathrm{T})$, relative humidity $(\mathrm{RH})$, and wind 
TABLE 3: The geographical locations for meteorological station used in this research (adapted from DGMET).

\begin{tabular}{lccc}
\hline Station & Latitude $(\mathrm{N})$ & Longitude $(\mathrm{E})$ & Altitude $(\mathrm{m})$ \\
\hline Nizwa & 22.859075 & 57.546294 & 881 \\
Rustaq & 23.40925 & 57.428611 & 322 \\
Samail & 23.254441 & 57.92753 & 430 \\
Samail-old & 23.309 & 57.948056 & 417 \\
Ibra-old & 22.7402 & 58.505 & 469 \\
Ibri & 22.809554 & 58.460511 & 516 \\
Saiq & 23.073972 & 57.666528 & 1993 \\
Ibri & 23.195417 & 56.429444 & 323 \\
Buraimi & 24.233809 & 55.915469 & 372 \\
Buraimi-old & 24.241 & 55.7869 & 299 \\
Bahla & 22.91222 & 57.25722 & 520 \\
Jabal Shams & 23.237678 & 57.264325 & 2840 \\
Al-Mudhibi & 22.511528 & 58.124722 & 378 \\
Sunaynah & 23.722583 & 55.905972 & 258 \\
\hline
\end{tabular}

direction (WD) from DGMET weather stations were analyzed to complement the satellite data interpretation on tracking the TCs. The Tropical Rainfall Measuring Mission (TRMM) Multi-Satellite Precipitation data is used to confirm the accuracy of the observed rainfall during the study period.

Radiosonde is used to determine the upper air profile including wind pattern and to calculate the convective temperatures for convection initiation. Due to the unavailability and limitation of the radar data over the study area, three analysis tools (DCMP RGB, BTD, BT: IR10.8 (brightness temperature) which are defined earlier) were used by relying on Meteosat Second Generation Satellite data to classify the precipitation cloud type during the reported cases. Using the RGB compositions "day cloud microphysical" (DCMP) which is the preferable RGB for observing cloud physical properties such as clouds and precipitations types and size during daylight hours, it is a composite of three channels: red: vis $0.8 \mu \mathrm{m}$ reflectance, green: $3.9 \mu \mathrm{m}$ solar reflectance which is very sensitive to cloud particles, IR3.9 reflectance is low for large ice particles but relatively high for small ice particles, and blue: $10.8 \mu \mathrm{m}$ BT [22].

WV6.2 and IR10.8 channel brightness temperature difference (BTD) is crucial in distinguishing between a high-level thunderstorm and low-level/midlevel clouds such as stratiform clouds. IR window band can typically detect mid- and low-atmospheric warmer layers more than WV6.2 band that is more sensitive to the upper troposphere moisture between $600 \mathrm{hPa}$ and $300 \mathrm{hPa}$. The storm with cold anvil (deep convection) has a BTD range of (4-6) K as WV6.2-IR10.8 is usually positive, since the IR has high negative temperature value and the BT in WV band is warmer than BT in IR window band. However, negative BTDs are an indicator for low-/midlevel clouds [23]. In brief, the IR10.8 brightness temperature (BT), derived from 15 minutes data of Meteosat-9 and Meteosat-8, was used to identify the convection activation based on [13] as shown in Table 4.

As the TC "Gonu" is the only cyclone in this study period that did not cross Oman, the SSTs of the Arabian Sea were analyzed during the study period.
TABLE 4: The cloud top temperature scale used for the classification of the convection intensity (adapted from [13]).

\begin{tabular}{lc}
\hline The intensity of convection & Temperature range $(\mathrm{K})$ \\
\hline Nonactive & $T \geq 233$ \\
Active & $213<T<233$ \\
Very active & $T \leq 213$ \\
\hline
\end{tabular}

\section{Results and Discussion}

3.1. TC "Gonu". The category four tropical cyclone "Gonu" developed in the Arabian Sea during 1-7 June 2007. As shown in the best track map in Figure 2, it passed near the coast of Oman into the Sea of Oman at 0000UTC on 6 June 2007 (2007060600) as TC of category 1 with maximum sustained wind speed between 70 and 80 knots as estimated by DGMET. According to JTWC, the maximum 1-minute average sustained wind speed within the system reached 145 knots, and the MSLP was estimated as $898 \mathrm{hPa}$, whereas the maximum 10-minute average sustained wind speed by DGMET was reported between 115 and 135 knots. The direct impact of "Gonu" was between 00UTC and 12UTC on 6 June 2007 (2007060600-2007060612) when it crossed the northeastern coast of Oman.

The calculated convective temperatures from the radiosonde of 00UTC of the days 5 and 6 were $46.3^{\circ} \mathrm{C}$ and $29.5^{\circ} \mathrm{C}$, respectively (Figures $3(\mathrm{a})$ and $3(\mathrm{~b})$ ). The maximum recorded temperatures at the selected weather stations of the Al-Hajar mountains reached $40.1^{\circ} \mathrm{C}$ at Nizwa and $36.8^{\circ} \mathrm{C}$ at Buraimi on the 5th and 6th of June, respectively. However, the backing wind pattern from the upper air sounding of 5 th and 6th of June was associated with weak vertical wind shear yielding to an indication of the cold and dry air sinking which resulted in feeble convection activity. This attributes to weak environmental lapse rate despite the abundance of the moisture content in the lower troposphere. It is, thereby, giving rise to more stratiform precipitation that is associated with nimbostratus clouds that generate from the outflow of the TC [24]. Overall, the cloud structure over the mountain area can be clearly seen on the Meteosat-9 in DCMP RGB as thick cloud in orange-violet tone with negative BTD value (Low- to midlevel water clouds with bigger water droplets/ 


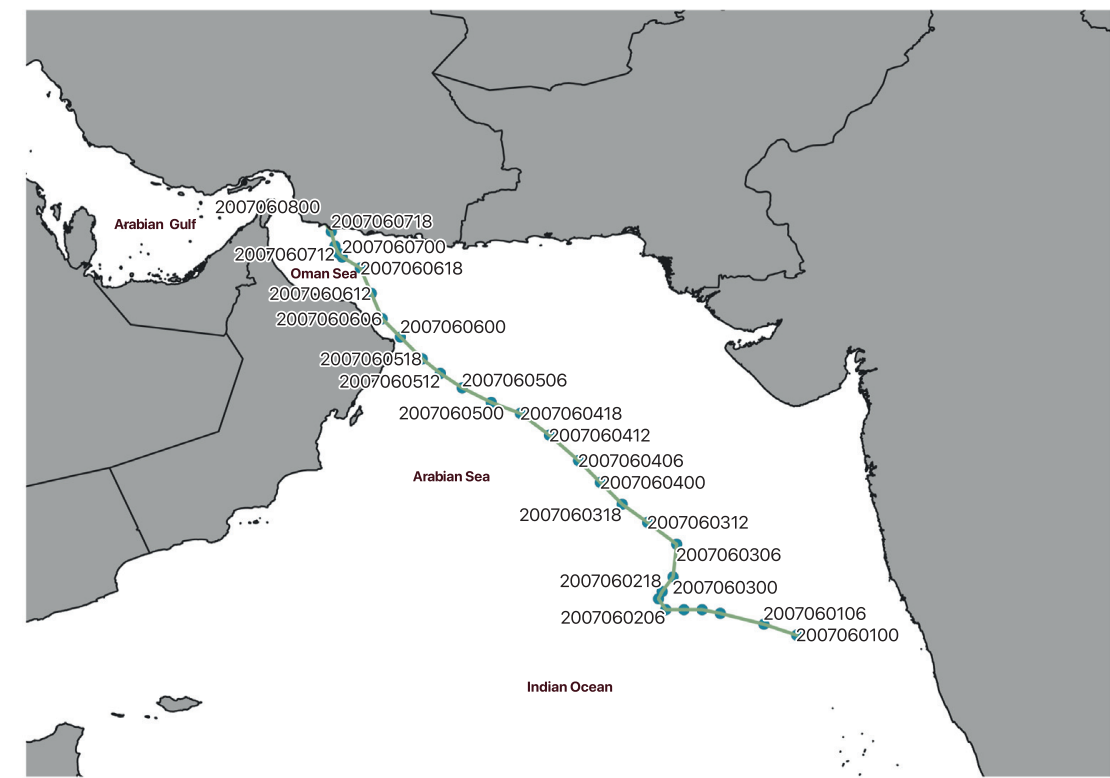

FIgURe 2: The best track of the TC "Gonu" (source: JTWC).

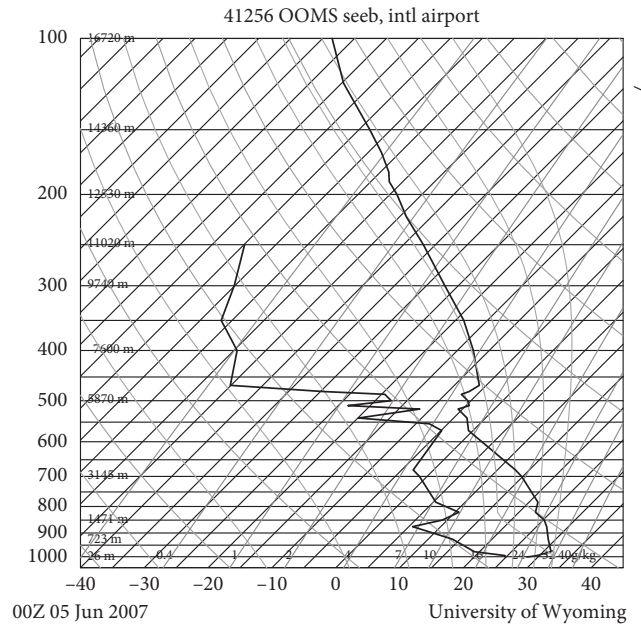

(a)

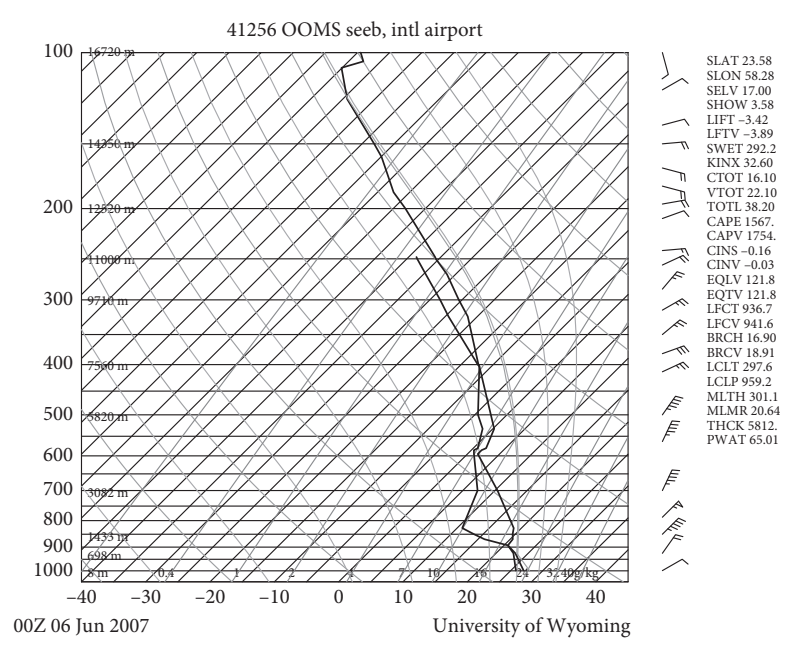

(b)

FIGURE 3: The upper air sounding on (a) 5th of June 2007 (b) 6th of June 2007 (source: University of Wyoming, 2007). The vertical distribution of wind is indicated by wind barbs on the right of the graph.

precipitated clouds) mixed with high clouds (Figures 4 and 5).

As TC "Gonu" moved towards the Sea of Oman, its intensity declined as it encountered colder sea surface temperature in the Arabian Sea (Figures 6(a) and 6(b)). A spatial variation was reported in the wind direction (Figure 7(a)); however, the convergence of moist easterly flow on 5th of June towards the mountains can explain the occurrence of the rain in the following day especially in Samail, Rustaq, and Ibra as can be seen in Figures 7(b) and $7(\mathrm{c})$. However, on the 6 th of June, $\mathrm{RH} \%$ exceeded $75 \%$ (Figure $7(\mathrm{~d})$ except in Buraimi weather station that is located on the lee side of the Al-Hajar Mountains, but the westerly flows were more likely of limited rainfall parallel to the observed low temperatures trends in the mountains on the 5 th and 6th of June (Figure 7(a)).

Despite the severity of the cyclonic system, the highest recorded precipitation was in the coastal stations compared to that in the Al-Hajar Mountains. Overall, the estimated rainfall by NASA's TRMM daily accumulated precipitation estimates (Figure 8) matches the areas of positive BTD (WV6.2; IR10.8) value; deep storms with very cold tops (IR10.8 $\mu \mathrm{m} \mathrm{BT}$ is less than $200 \mathrm{~K}$ in red color) and strong updrafts along the northeast coast as indicated by the satellite imagery sequence (Figure 4). Most of this rainfall was from storms within the system, except the development of a very active convection on 5 th June $1800 \mathrm{UTC}$ with the very cold temperature that reached $193 \mathrm{~K}\left(-80^{\circ} \mathrm{C}\right)$ and $\mathrm{BTD}$ value 


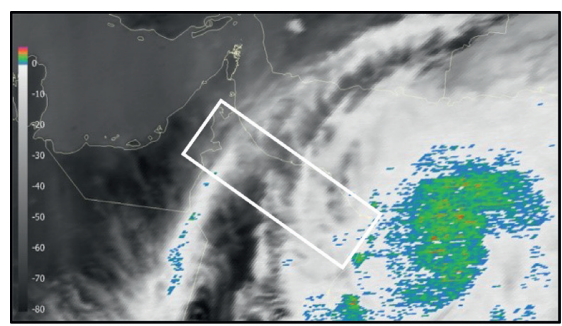

2007-06-04 10:00 UTC

(a)

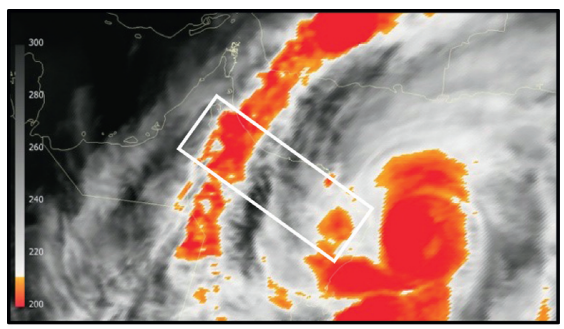

2007-06-05 15:00 UTC

(d)

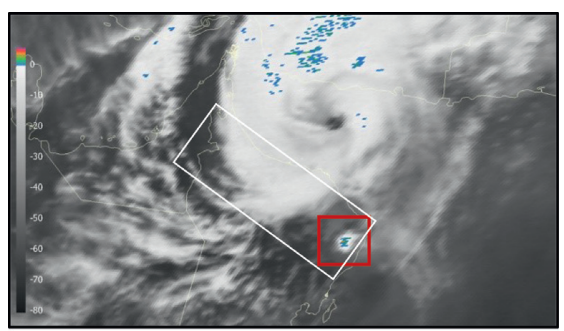

2007-06-06 18:00 UTC

(g)

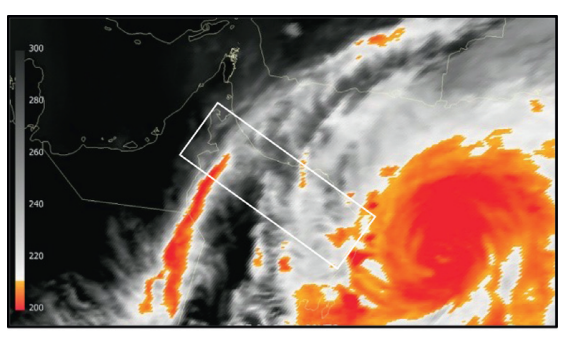

2007-06-04 10:00 UTC

(b)

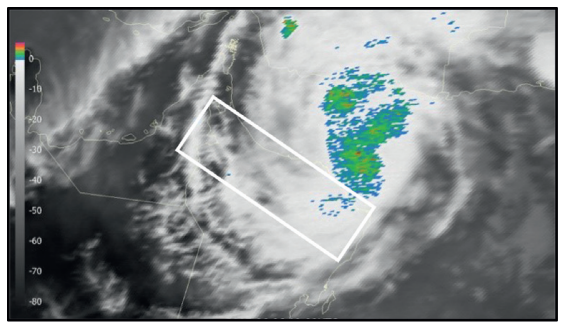

2007-06-06 10:00 UTC

(e)

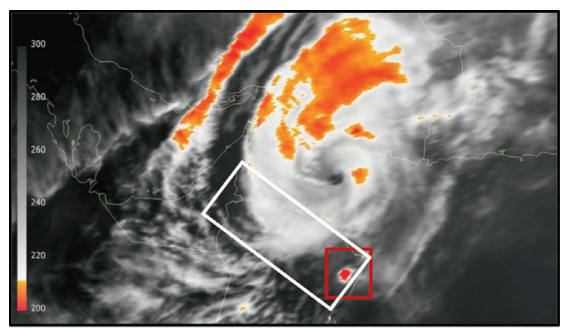

2007-06-06 18:00 UTC

(h)

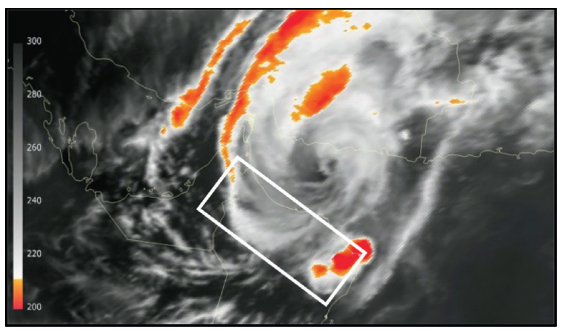

2007-06-06 20:00 UTC

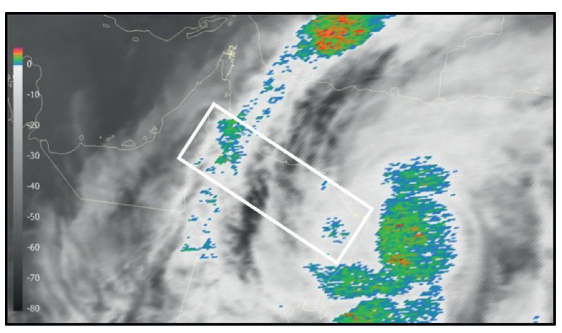

2007-06-05 15:00 UTC

(c)

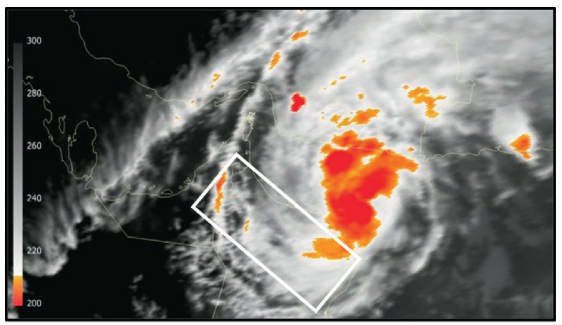

2007-06-06 10:00 UTC

(f)

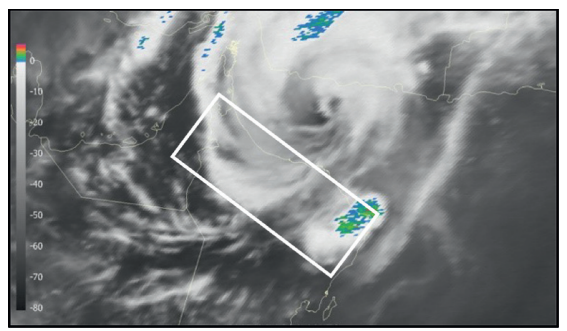

2007-06-06 20:00 UTC

(i)

(j)

FIGURE 4: Sequence of BTD (WV6.2 $\mu \mathrm{m}$; IR10.8 $\mu \mathrm{m}$ ) (right) and coldest brightness temperature IR10.8 $\mu \mathrm{m}$ (left) on 5th and 6th of June.

of 5 on the desert behind the eastern part of the Al-Hajar Mountains (Figures $4(\mathrm{~g})-4(\mathrm{j})$.

Over the mountain, the highest 24-hour rainfall was reported on the 6th of June in Samail with a total of $87.2 \mathrm{~mm}$. However, the local maximum recorded rainfall in 1 hour was $17.8 \mathrm{~mm}$ at 8 am local time at Rustaq station that was classified as moderate rainfall, where the $\mathrm{RH} \%$ was $98 \%$.

Continuous rainfall record with a low average rate was observed, but the highest hourly recorded amount was $17.8 \mathrm{~mm}$ at Rustaq station, indicating the stratiform precipitation that has a lower rate than deep convection rate [25].
A limited impact of the tropical system was observed on the western part of the mountain. Only advected medium and high clouds were observed on the western part of the AlHajar Mountains, where no rain was reported at Buraimi station. Despite the fact that the "coldest temperature" of the cloud arc is shifting over Buraimi (Figures 4(c) and 4(d), the cloud tops are very high and the DCMP images indicate opaque clouds, which could suggest precipitating clouds (Figure 5). However, the lower tropopause was probably quite dry because of the westerly dry flows that evaporated most of the precipitation formed in the cloud arc. 


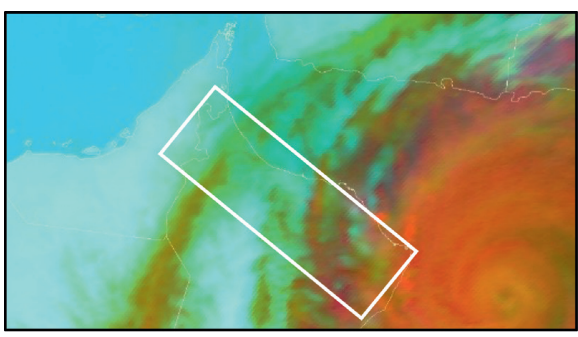

2007-06-05 10:00 UTC

(a)

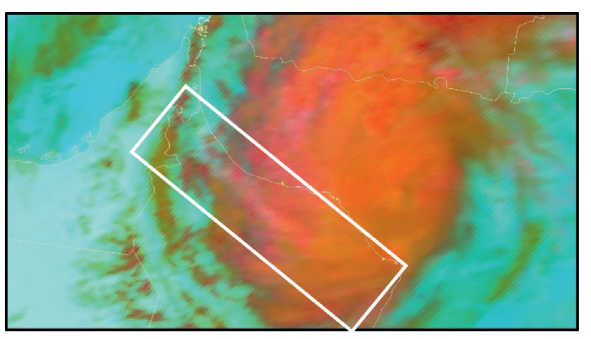

2007-06-06 09:00 UTC

(c)

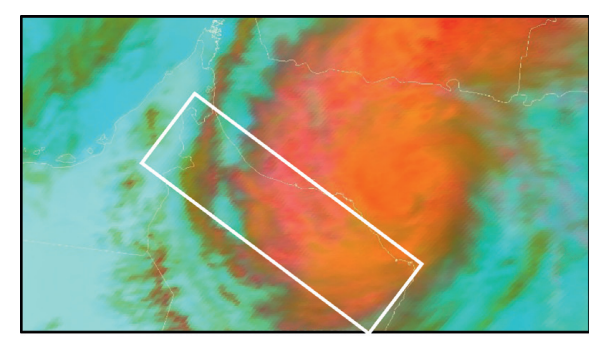

2007-06-06 08:00 UTC

(b)

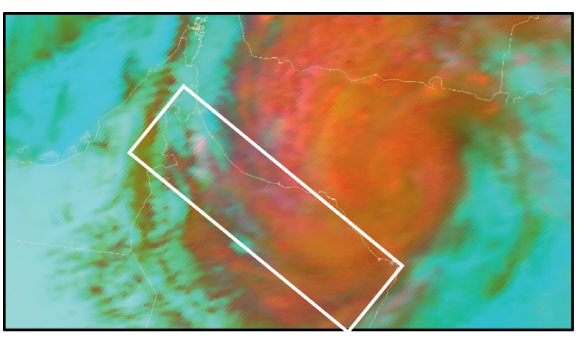

2007-06-06 10:00 UTC

(d)

FIGURE 5: Sequence of day microphysical RGB composition images on 5th and 6th of June. The color scheme is useful to detect cumulonimbus (red), optically thick clouds with small ice particles on top (orange), and thin clouds with small ice particles (light green).

Analysis SST

05-06-2007 to 06-06-2007

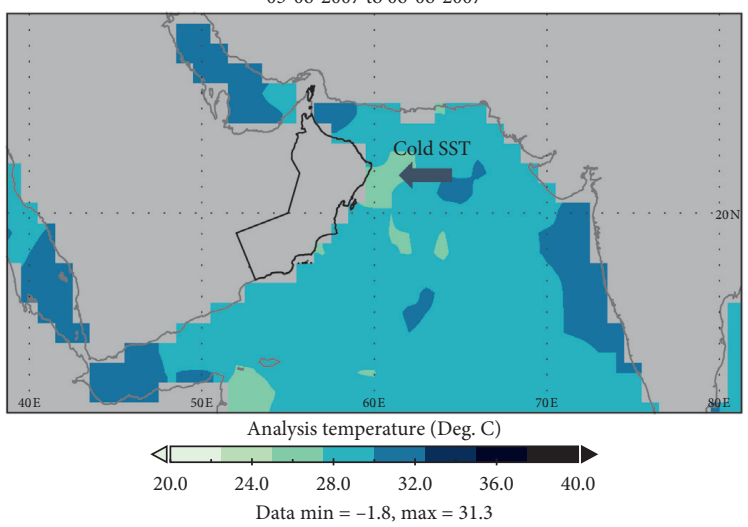

(a)

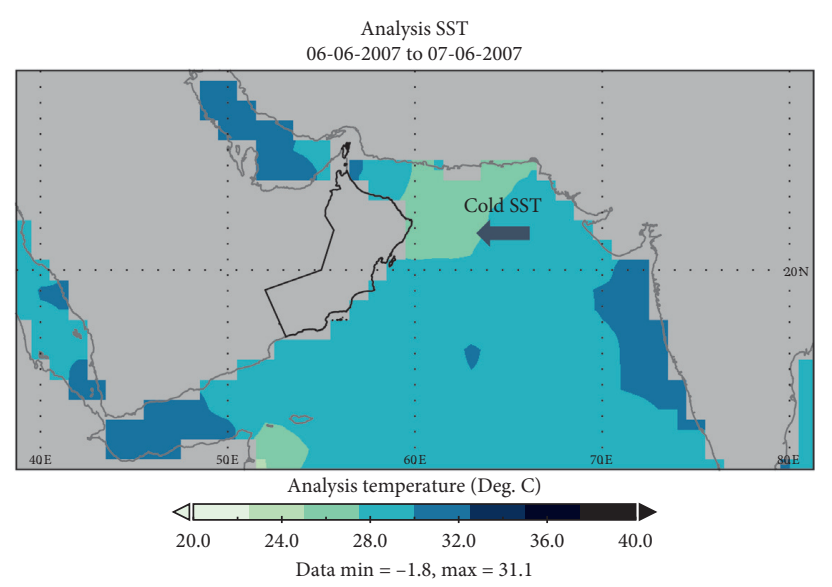

(b)

Figure 6: The Sea Surface Temperatures in ${ }^{\circ} \mathrm{C}$ on (a) 5th of June 2007 (b) 6th of June 2007 at 04 LT with spatial resolution (100 KM) (Source: NOAA, 2020).

3.2. "Phet". In contrast to TC "Gonu," the third category TC "Phet" crossed Oman on 0000UTC 4 June 2010 (2010060400) and made landfall as TC of category two with an estimated maximum sustained wind speed of about 84 knots as per DGMET. The MSLP of "Phet" by JTWC was estimated as $929 \mathrm{hPa}$, and the maximum 1-minute average sustained wind speed around its center was about 125 knots. However, the maximum 10-minute average sustained wind speed as estimated by DGMET was 97 knots. The track of "Phet" (Figure 9) was among the rarest tracks seen since 1877 because of having the longest track of 8 days between 31 May and 7 June, exceeding the average life period of a TC of 4-5 days [26]. The calculated convective temperature from the sounding data on
0000UTC 3 June 2010 indicated that the convective temperature value was $33.2^{\circ} \mathrm{C}$ (Figure $10(\mathrm{a})$ ), whereas the sounding of June 4 was slightly lower $\left(31.9^{\circ} \mathrm{C}\right)$ (Figure $\left.10(\mathrm{~b})\right)$. However, the maximum recorded temperature on the 3rd of June was higher than the temperatures on the day of convective temperature in all the stations in this study (Figure 11(a)). Nevertheless, the observed maximum temperatures in 4 out of 9 stations were higher than the convective temperature on the 4th of June, particularly Nizwa, Sunaynah, Buraimi, and Ibri. Despite this, on 3rd June, only light rain was reported at Ibra station between 21:00 and 22:00 local time while moderate easterly wind breeze derived sufficient moisture convergence in the lower troposphere with RH\% within the range of $85 \%-88 \%$ (Figure $11(\mathrm{~d})$ ). 

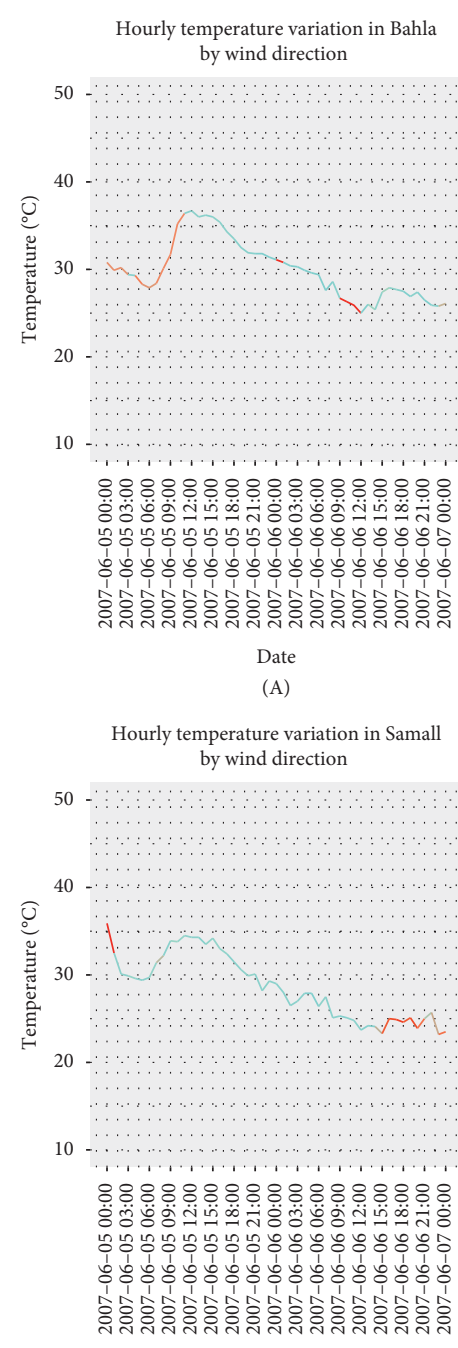

Date

(D)
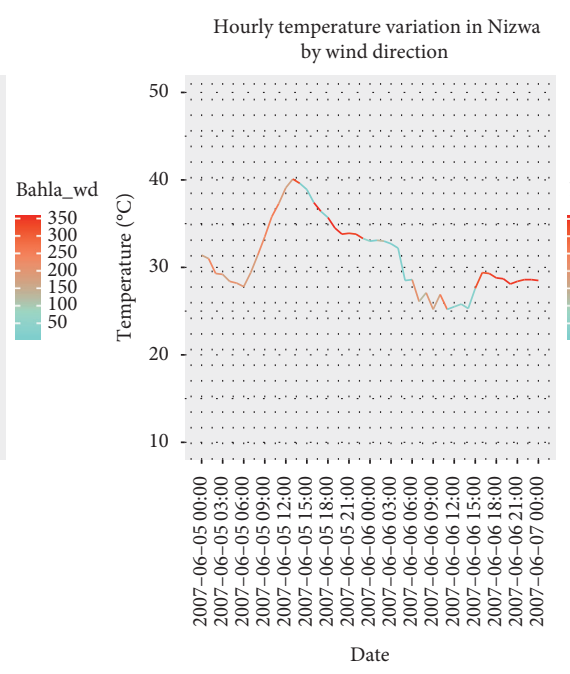

(B)

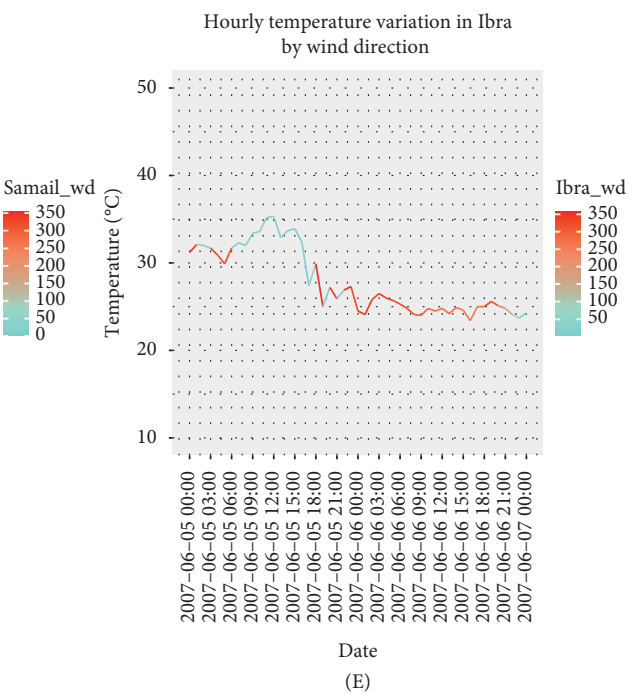

(a)

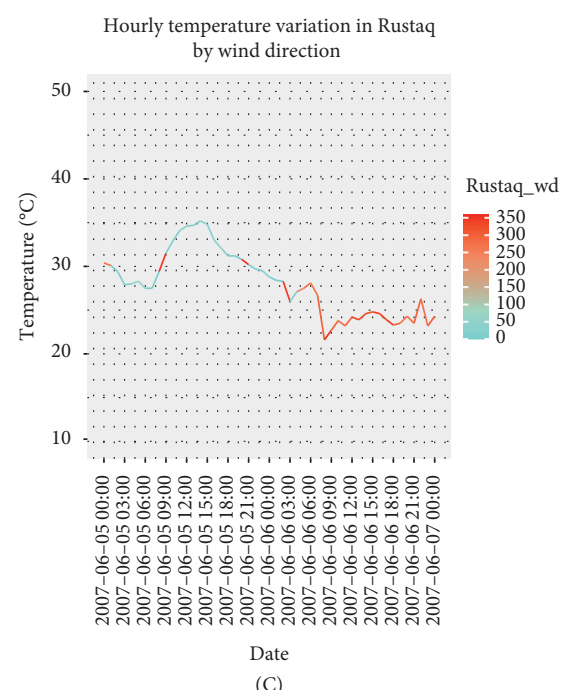

Hourly temperature variation in Buralml by wind direction

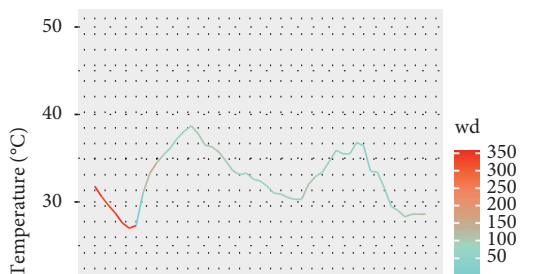

20

10

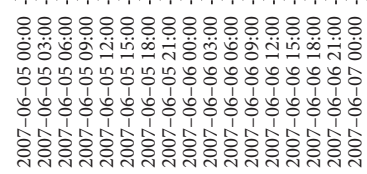
Date

(F)

Figure 7: Continued. 


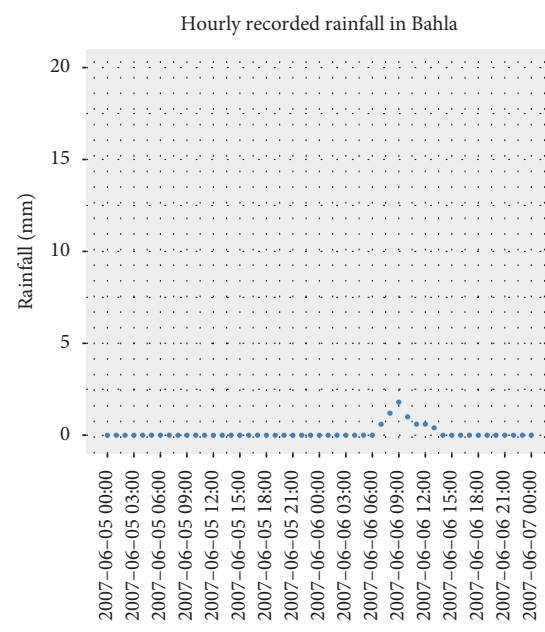

Date

(A)

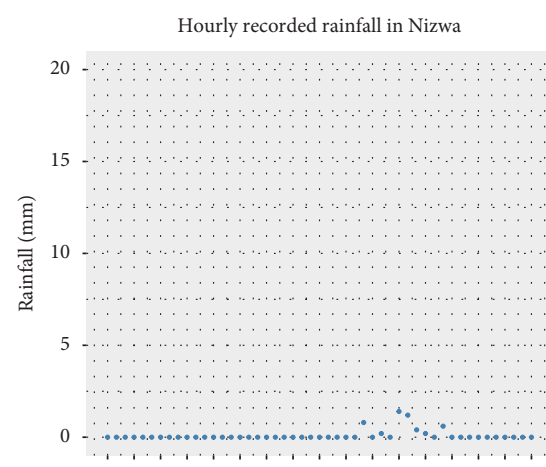
o o o o o o o o o o o o o o o o o

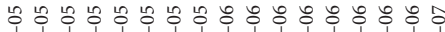

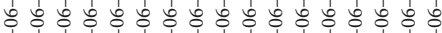

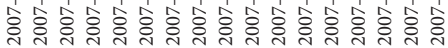

Date

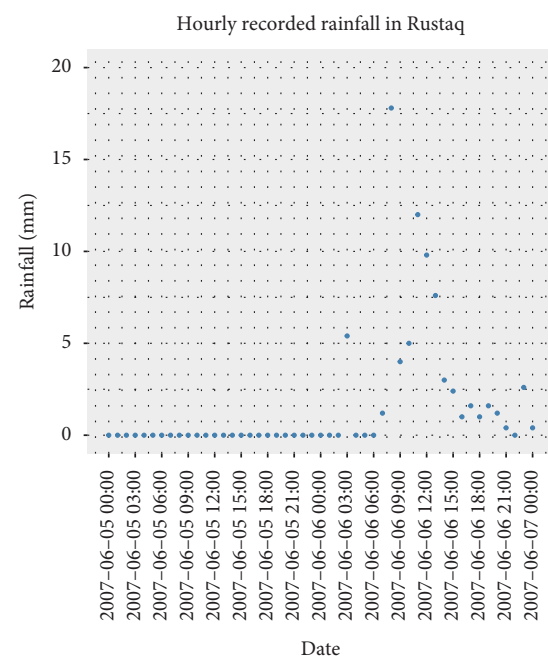

(C)

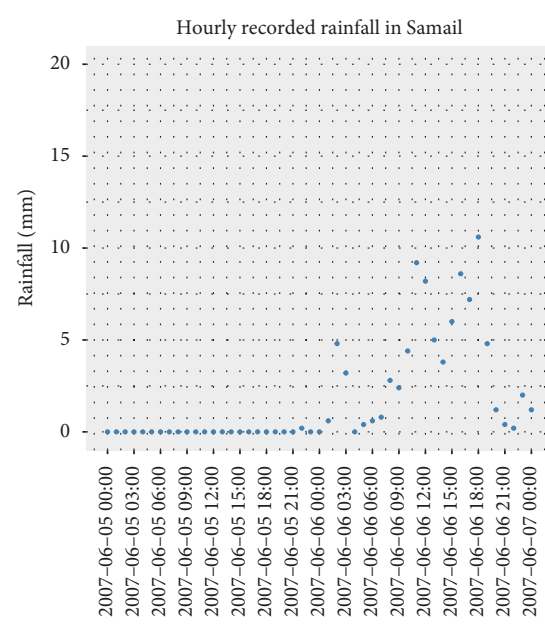

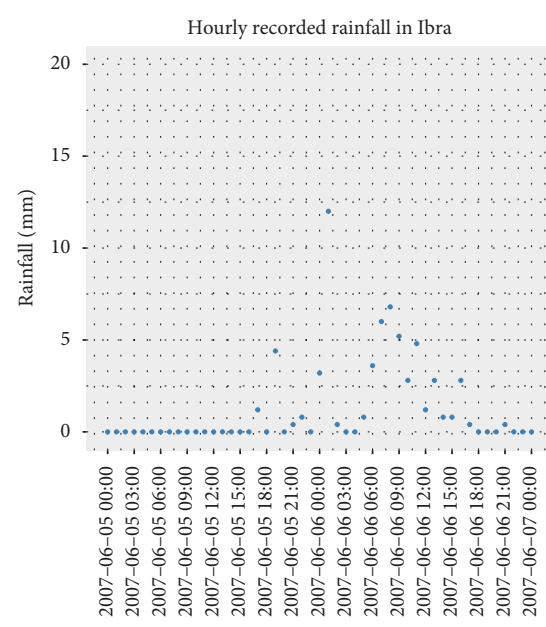

Date

(b)

Figure 7: Continued. 


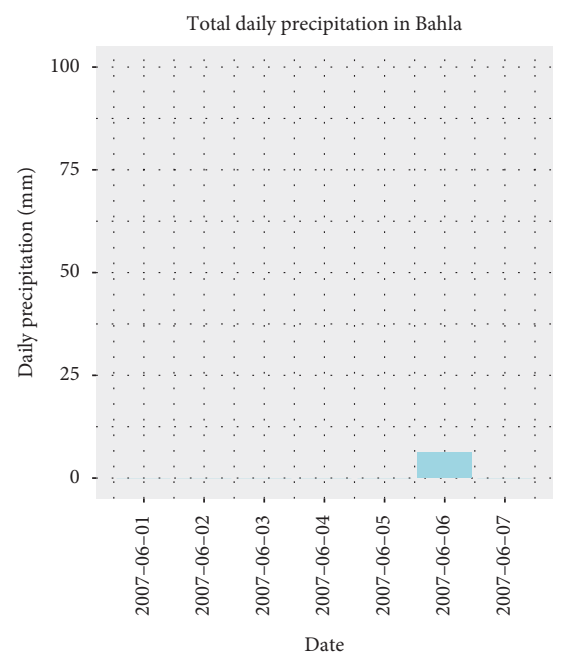

(A)

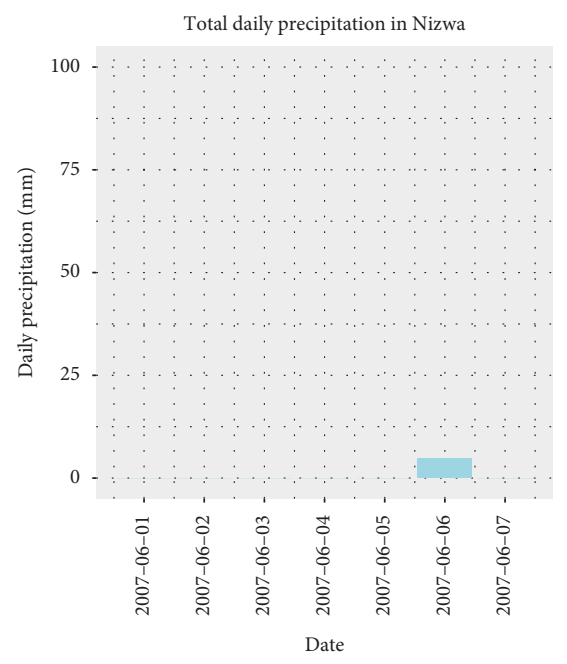

(B)

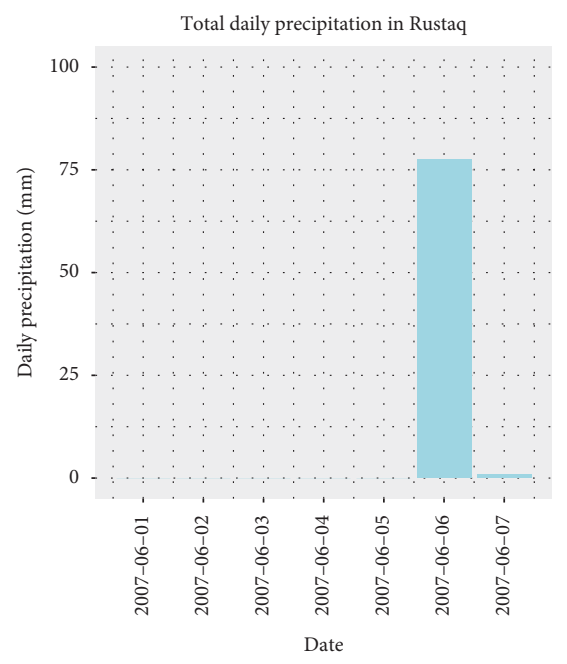

(C)

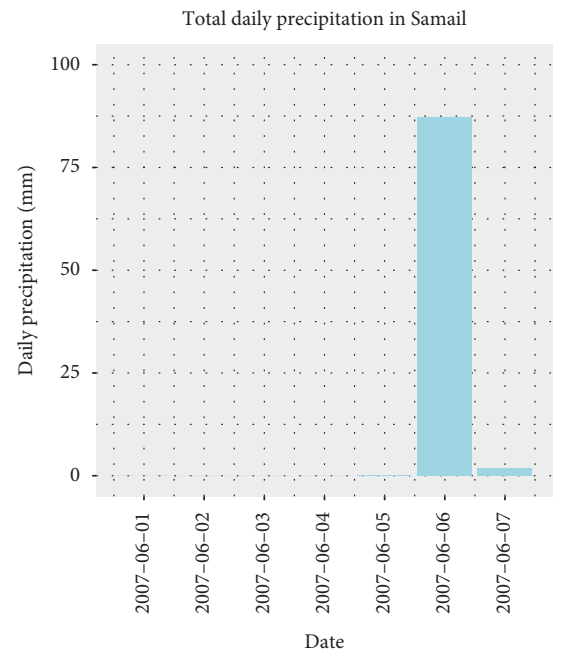

(D)

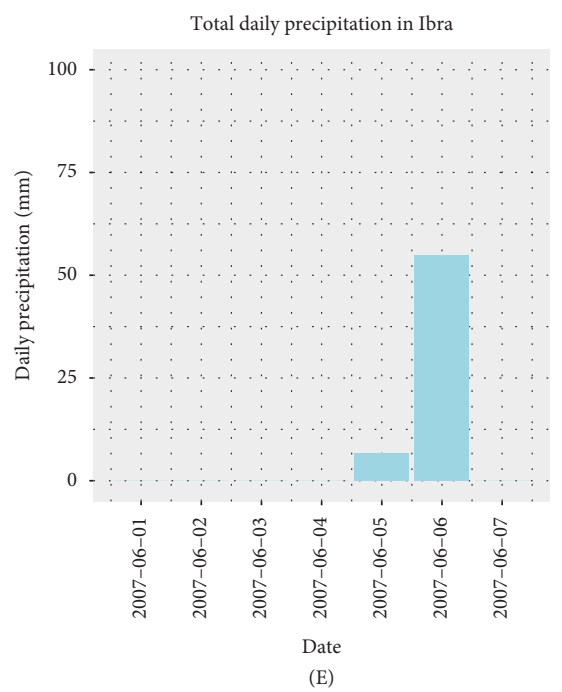

(c)

Figure 7: Continued. 


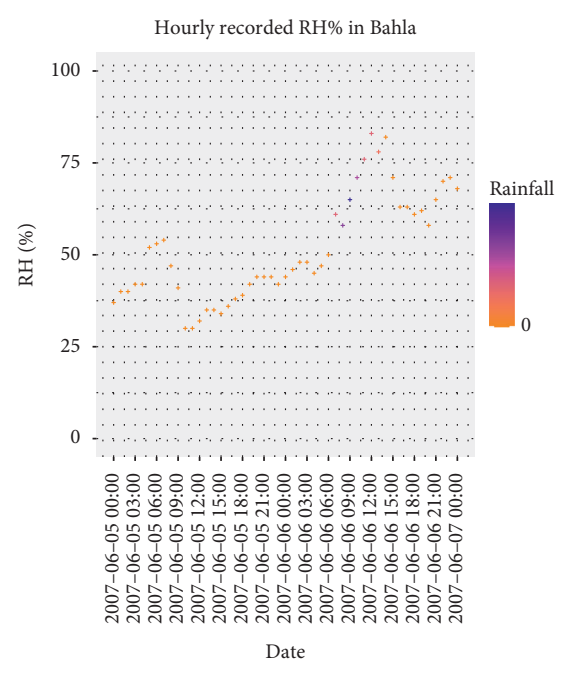

(A)

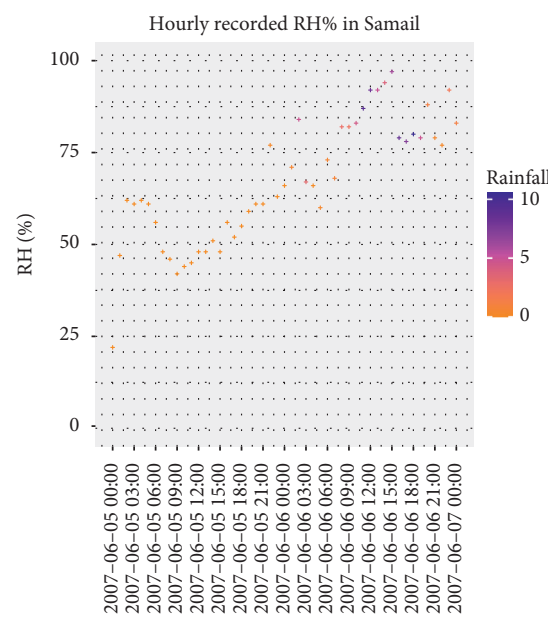

Date

(D)

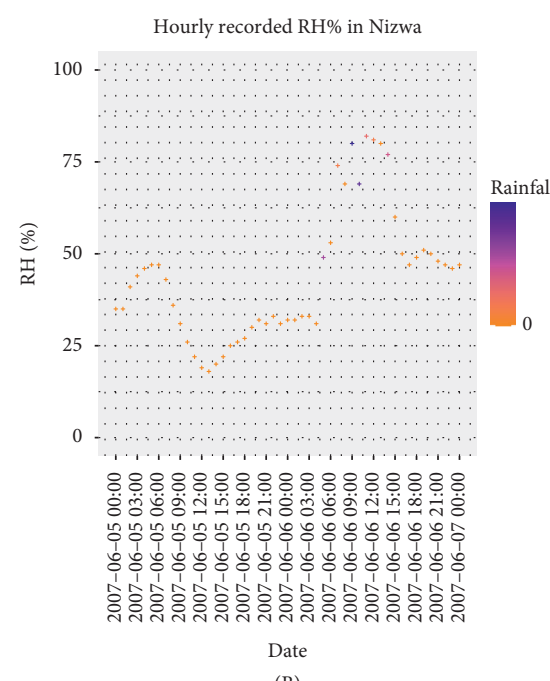

(B)

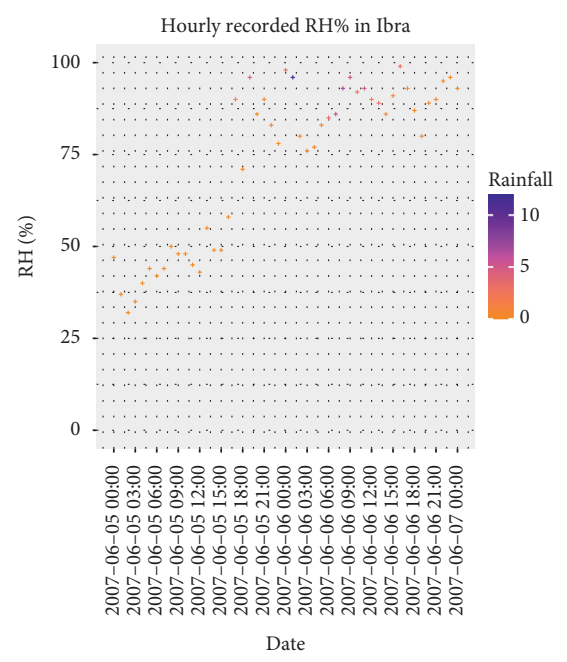

(E)

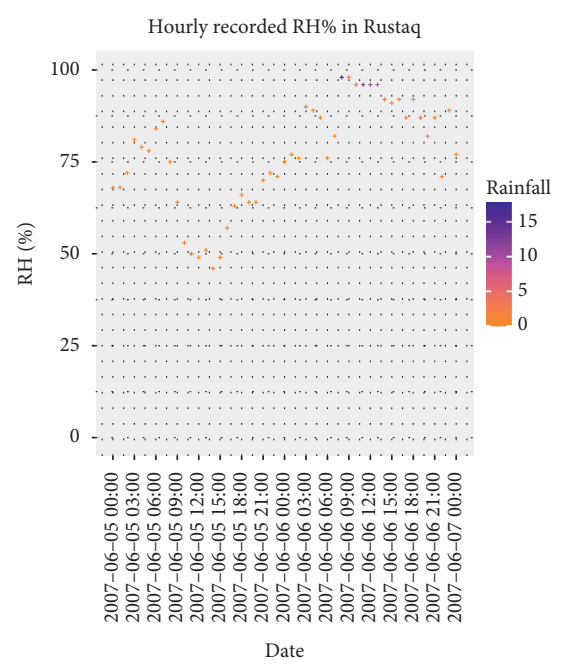

(C)

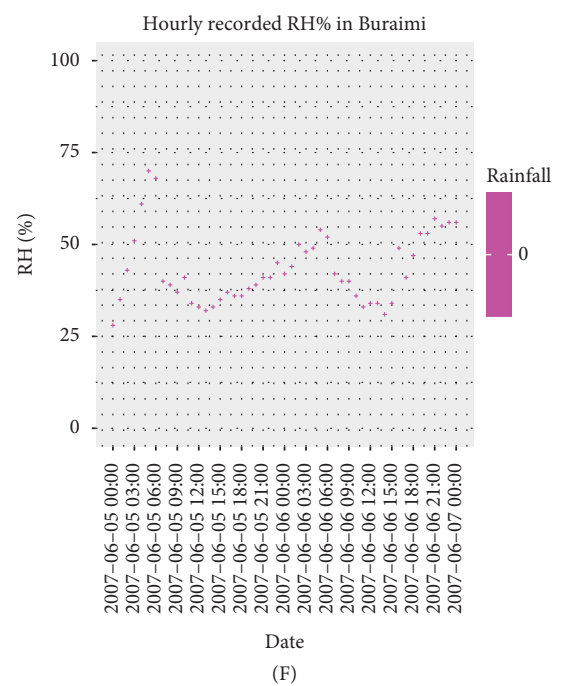

(d)

Figure 7: (a) Hourly temperature variation in ${ }^{\circ} \mathrm{C}$ with respect to the wind direction at some weather stations on the Al-Hajar Mountains during TC "Gonu." (b) Hourly precipitation ( $\mathrm{mm}$ ) at some weather stations on the Al-Hajar Mountains during TC "Gonu." (c) Daily precipitation ( $\mathrm{mm}$ ) at some weather stations on the Al-Hajar Mountains during TC "Gonu." (d) Hourly RH\% variation with respect to the wind direction at some weather stations on the Al-Hajar Mountains during TC "Gonu."

At those stations whose maximum temperatures exceeded the convective temperature on the 4 th of June, the intensity of the rainfall did not exceed the light rain, and it was almost continuous from 04:00 to 21:00 local time, with the highest hourly value being $1.4 \mathrm{~mm}$ and daily accumulated value of $6.8 \mathrm{~mm}$ in Nizwa station as shown in Figures 11(b) and 11(c), respectively. On the other hand, the highest precipitation record in $1 \mathrm{hr}$ was $18.8 \mathrm{~mm}$ that had reported in Rustaq station at 18:00 local time (Figure 11(b)).

The obtained results were consistent with the radiosonde wind profile in Figure 10(a) as the wind was backing on the 3rd of June and the atmosphere above $800 \mathrm{hPa}$ was perturbed with dry air. By approaching the tropical system on the 4th of June, the strength radial outflow from the system can explain the suppressed strong convection. This is consistent with [27] finding that the convection is more intense in the inner core of the TC and weaker in the outer band compared to the inner band. Other than this, another study indicated that the stratiform precipitation in the inner core and inner band of the tropical cyclone is higher compared to the convective rainfall [27]. The heat conduction to the higher levels synchronizing with the TC intensity can interpret the likelihood of the stratiform rain [27] rather than the convective rain which requires further cooling to trigger the instability of the atmosphere [28-31]. Apart from this, as the tropical cyclone intensifies, the subsidence outside the inner core radii to the inner band limits the deep convection development [27].

The convection location is dependent on the distribution of water vapor in the lower troposphere [32]. Our results suggest that there may have been reduced convection on June 3 rd and 4th. 
ear-real-time precipitation total

Accumulated rainfall estimates from NASA s TRMM 05-06-2007 to 06-06-2007

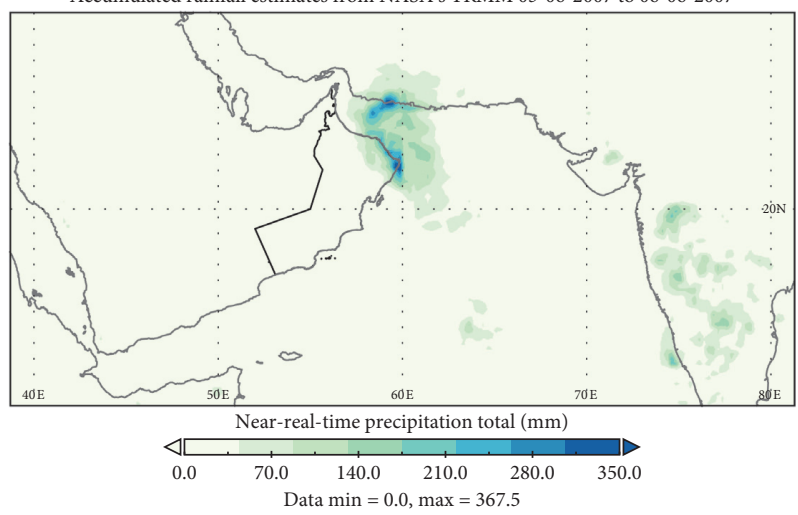

FIgURE 8: Near real-time daily accumulated rainfall estimates from NASA's TRMM satellite (0.25 degree) for 2 days (5-6) June 2007.

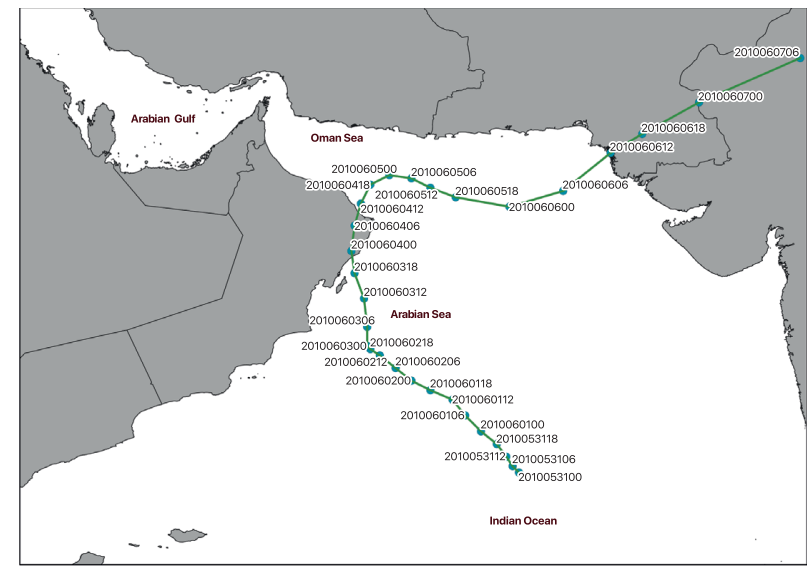

FIgURE 9: The best track of the TC "Phet" (source: JTWC).

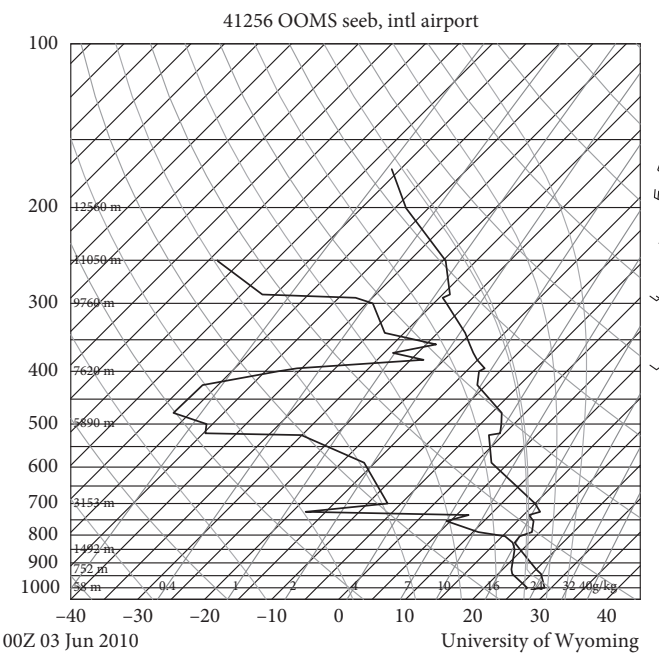

(a)

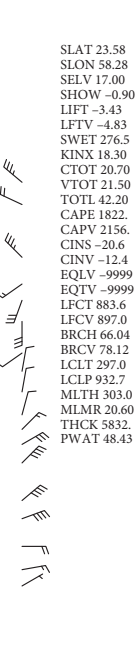

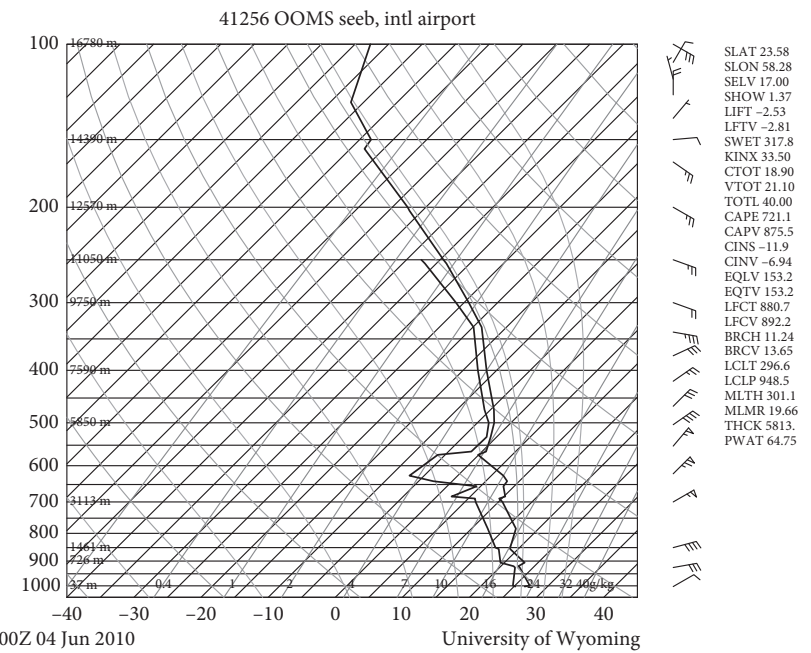

(b)

FIgURE 10: The upper air sounding on the (a) 3rd of June 2010 and (b) 4th of June 2010 (source: University of Wyoming, 2010).

From the multispectral imagery (DCMP RGB) in Figure 12, the direct impacts of TC "Phet" in Oman are seen as it made landfall in Oman on June 4th. On the 3rd of June, the northeastern part was under the effect of some cells with low- to midlevel thick water clouds with smaller particles (light green) at the edge of the band, while the transparent thin cirrus cloud (green fibrous) advected to the west over the mountain (Figure 12(b)). As "Phet" crossed the land 
(June 4), its inner clouds band with the severe storms covered most of the north of Oman and the Sea of Oman. The appearance of these storms is in bright orange (Figure 12(c)) with a cold top temperature below $213 \mathrm{~K}$ (range of the active clouds) and positive BTD value (Figures 13(e) and 13(f)) indicating small ice particles near tops with strong updraft. The intensity of these storms weakened that is indicated from the change in the color scheme in the DCMP RGB; bright orange (0700UTC, Figure 13(c)) to dark red/brown (1100UTC, Figure 12(e)) was largely showing the existence of massive ice particle in the cloud but with less chance of rain. This color change is owed to the sensitivity of the IR3.9 channel to ice particle size. Very heavy rainfall occurred in this region over the north and northeastern coastline as estimated by the accumulated rainfall estimates from NASA's TRMM Satellite (Figure 14).

On June 4th, satellite imagery (Figures $12(\mathrm{c})-12(\mathrm{e})$ and Figures 13(e)-13(1)) analysis shows the severity of the northeast part of the outer band with deep storms incomparable with mainly thick warm stratiform precipitated cloud (violet (large droplet)/green to yellow (small droplet) in DCMP) in the southwest band that covered the middle and west parts of the Al-Hajar Mountains. Although the BTD value of this band was negative; however, there was no indication from the IR10.8 BT for cold top temperature validating that there was no convection activity over the mountain as the continuous light rain recorded at the selected stations was only from medium- to low-level clouds (thick stratocumulus clouds).

A small convective cell with small positive BTD and top brightness temperature below $200 \mathrm{~K}$ was developed within the outer stratiform band (violet band) at the northern coast between 1030UTC and 1400UTC. From the subsequences of the satellite images (Figures 12(e), 13(g), and 13(h)), it was shown that the movement of the formed cells was toward the southwest and caused the highest amount 1-hour rain recorded at Rustaq station at 1400UTC as discussed earlier.

From the above analysis, there was no orographic convection developed over the mountain during "Phet" direct effect (June 3rd and 4th), and all the precipitation recorded at the selected station was from the system cloud bands.

3.3. TC "Mekunu". The second category "Mekunu" originated over the southwest of the Arabian Sea on 21 May 2018 with a consistent north-north-westward track (Figure 15) towards the south of Oman. The landfall of the system was reported on 25th between 1830UTC and 1930UCT near $16.850 \mathrm{~N} / 53.750 \mathrm{E}$ as deep depression with maximum sustained wind speed of about 28-33 knots according to DGMET. The maximum 10-minute average sustained winds of Mekunu were within the range of 85-90 knots, in contrast to JTWC where the maximum 1-minute average sustained winds of the system were about 100 knots with MSLP of $952 \mathrm{hPa}$, that is classified as TC of category three.

An extreme dryness existed on 24th and 25th through the whole troposphere as it was indicated from the radiosondes (Figures 16(a) and 16(b)). In WV7.3 $\mu \mathrm{m}$ satellite image (channel sensitive to the water vapor concentration mainly between $700 \mathrm{hPa}$ and $500 \mathrm{hPa}$ (Figure 17), the existence of middle troposphere dryness is indicated as extended dark strip from the northeast (Pakistan).

Considering the moisture content in the planetary boundary layer (PBL), the sounding profiles in Figures 16(a)-16(c) were used to calculate the dewpoint depression of the lowest $50 \mathrm{hPa}$, and the obtained values were $19.3^{\circ} \mathrm{C}, 31.5^{\circ} \mathrm{C}$, and $14.8^{\circ} \mathrm{C}$ for days 24 th, 25 th, and 26 th, respectively. As the dewpoint depression is equal to the difference between the temperatures and the dewpoints, it can reveal the vertical distribution of the moisture especially when its calculation is based on the PBL. More recently, [13] reported that the threshold value of the mean of dewpoint depression in the lowest $50 \mathrm{hPa}$ required for the active convection is $12^{\circ} \mathrm{C}$. Accordingly, the results of the dewpoint depressions reflect the dryness and lack of water vapor in the PBL which were sufficient to suppress the convection initiation.

With the passage of the system towards the inland, this dryness slightly weakened on day 26 as shown in Figure 16(c) due to the change in the wind pattern, while more humid air was advected from the Arabian Sea to the mountains with the entrance of the system. This can explain the lower value of the dewpoint depression on the same day compared to May 24 and 25.

The convective temperature values were $47.4^{\circ} \mathrm{C}, 56.2^{\circ} \mathrm{C}$, and $43.3^{\circ} \mathrm{C}$ for 24 th, 25 th, and 26 th, respectively, which was higher than the maximum recorded temperature in all the Al-Hajar weather stations included in the present study as previously shown in Figure 18(a). Assuring that the air near the surface attained a negative buoyancy and inhibited ascending currents, no active convection was observed.

Furthermore, none of these days reported rainfall higher than $0.5 \mathrm{~mm}$ (Figure 18(b)). Only traces of rain that was $0.4 \mathrm{~mm}$ was reported in $1 \mathrm{hr}$ on 25th at 17:00 local time at the Al-Mudhaibi weather station (Figure 18(b) F)), and that was the highest among the Al-Hajar stations. This result was consistent with TRMM estimated rainfall during 24th, 25th, and 26th as no significant precipitation was indicated in Figure 19.

All satellite methods used in this case (IR10.8 $\mu \mathrm{m}, \mathrm{BTD}$, and DCMP RGB) (Figures 20 and 21) indicated that nonactive convection developed over the mountain except for very weak cells (bright white in IR10.8 (Figure 20(h)). These cells started to develop in the foothill behind the eastern part of the mountains on 25th May at 1100UTC (15:00 local time) and caused the trace precipitation $(0.4 \mathrm{~mm})$ recorded at the Al-Mudhaibi station at 1400UTC (18:00 local time). The interpretation of cloud type in DCMP RGB (Figure 21(d)) was difficult due to the low sun angle. However, the cells were still identified as two dark brown bombs. Since the cells were weak, BTD was negative.

During the three days of Mekunu, the direct impact was over Salalah, mainly 24th, 25th, and 26th of May. However, the Mekunu's upper outflow clouds partially covered the north of Oman which steered with the upper air jet seen in airmass RGB, as a sharp boundary between red and green 
Hourly temperature variation in Bahla by wind direction

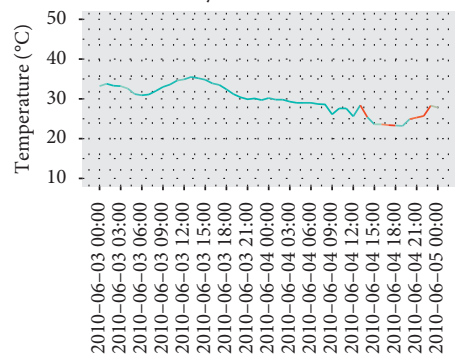

Date

(A)

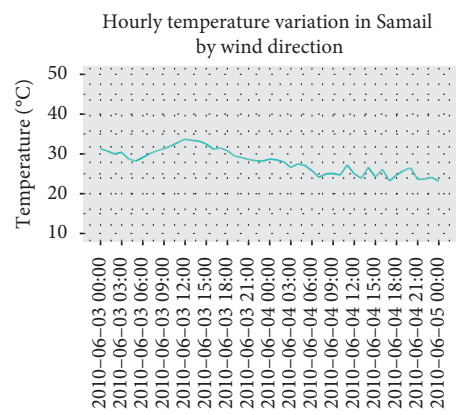

Date

(D)
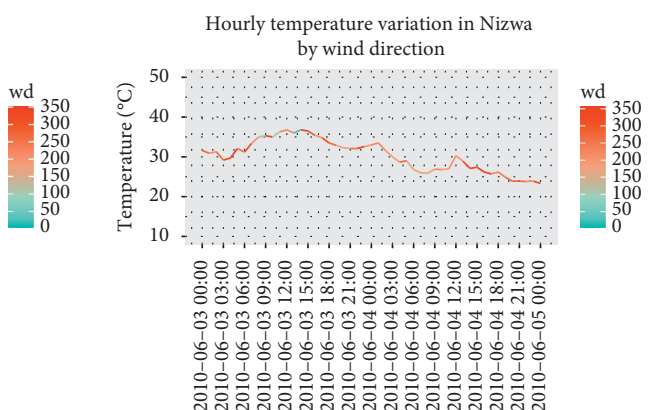

Date

(B)

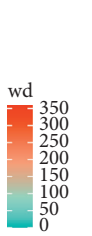

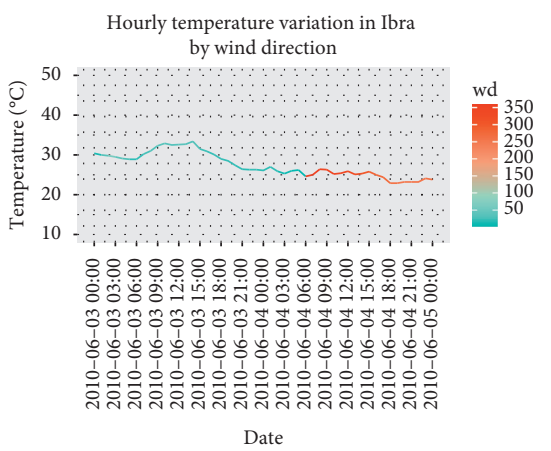

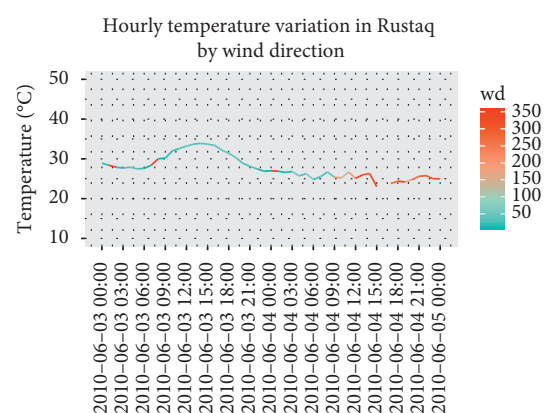

Date

(C)

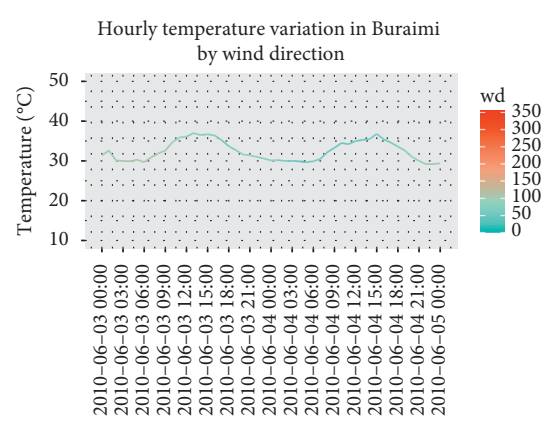

Date

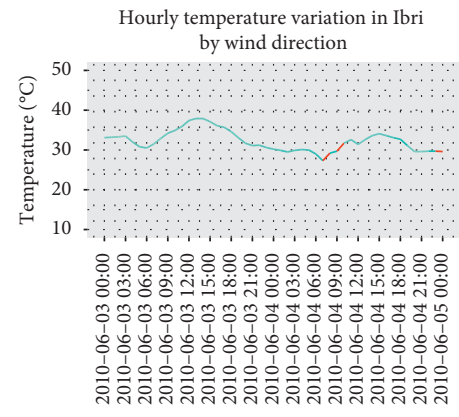

Date

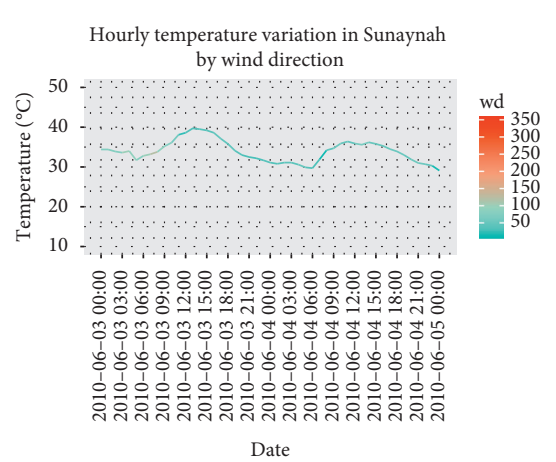

(H)

(a)

FIgURE 11: Continued. 


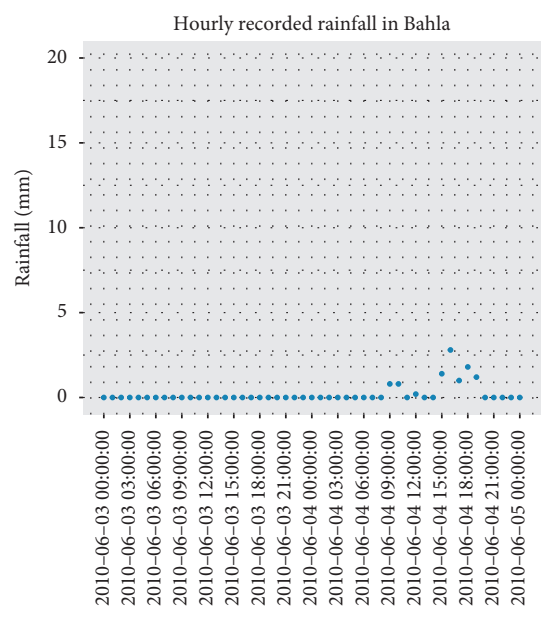

Date

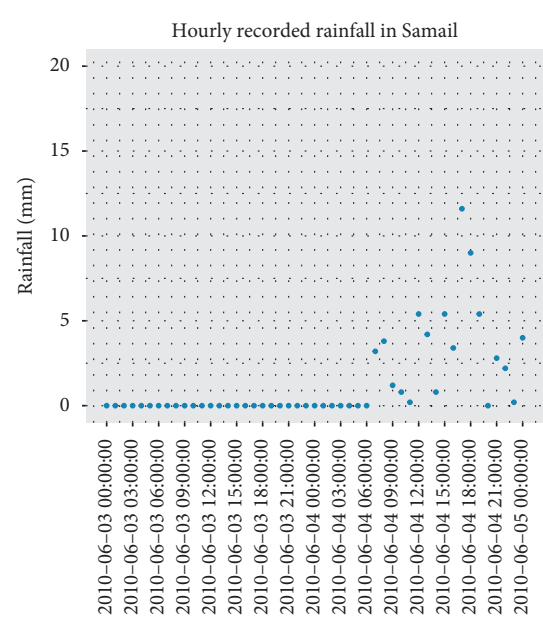

Date

(D)

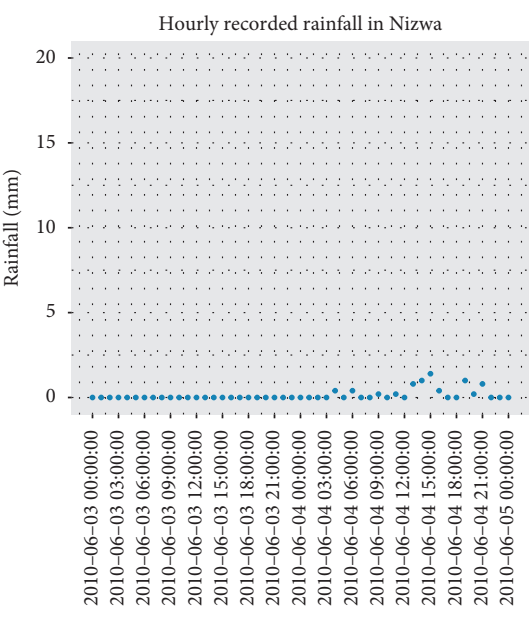

Date

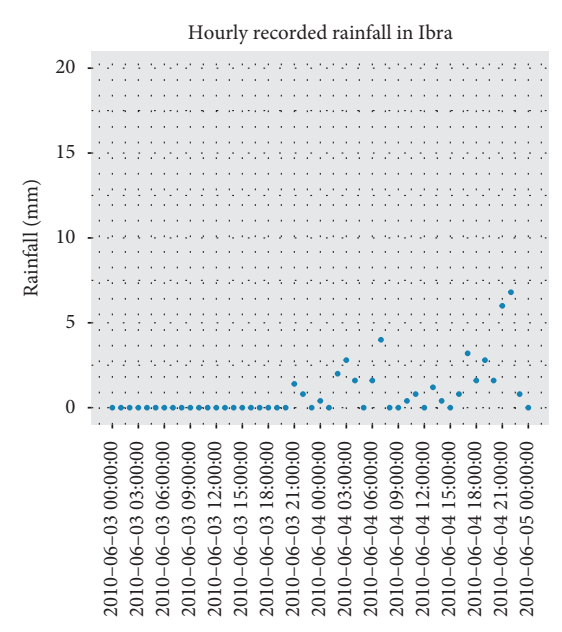

Date

(E)

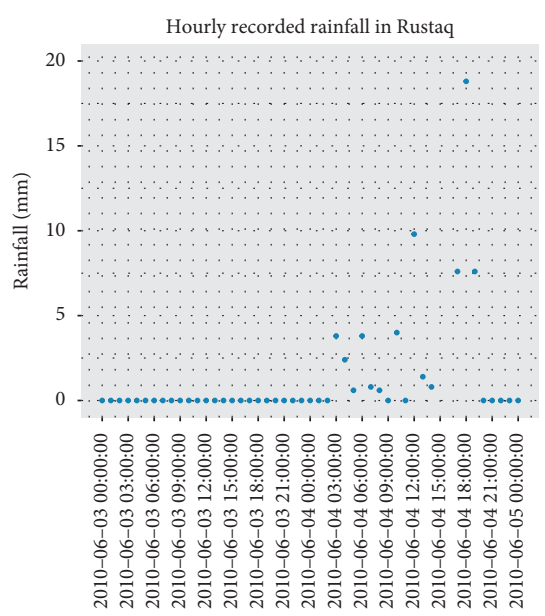

Date

(C)

(b)

Figure 11: Continued. 


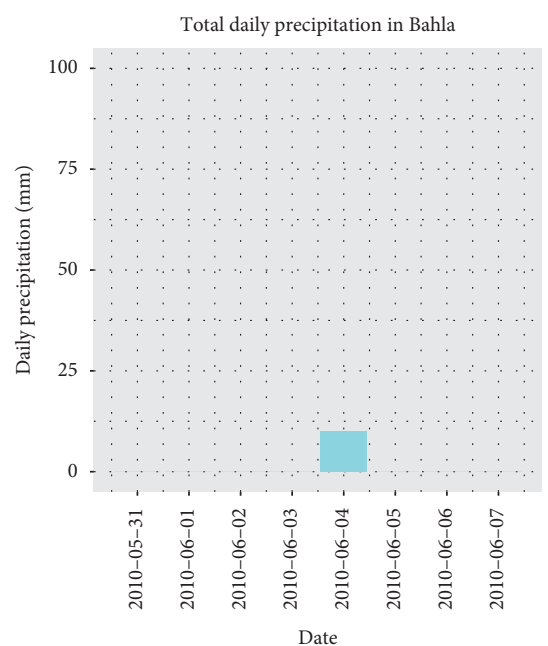

(A)

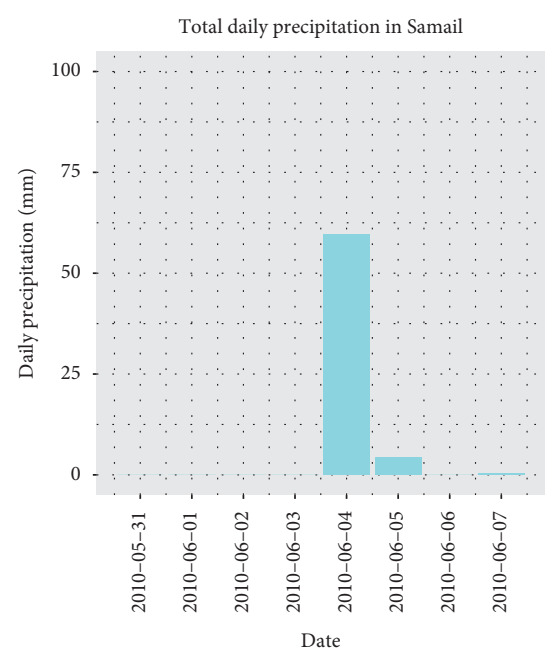

(D)

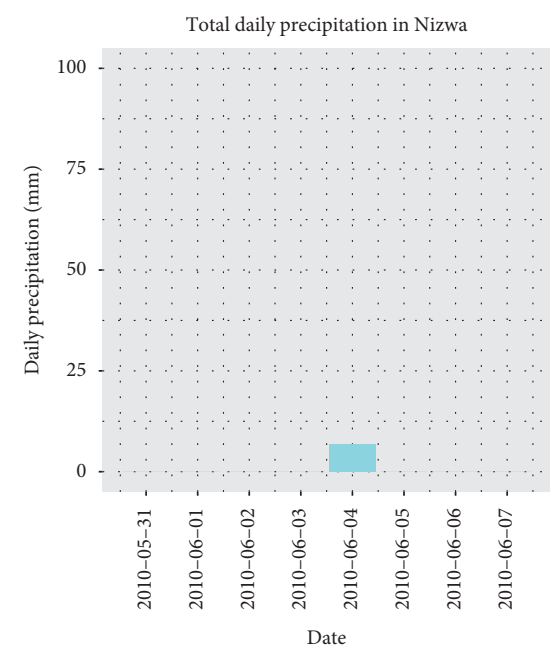

(B)

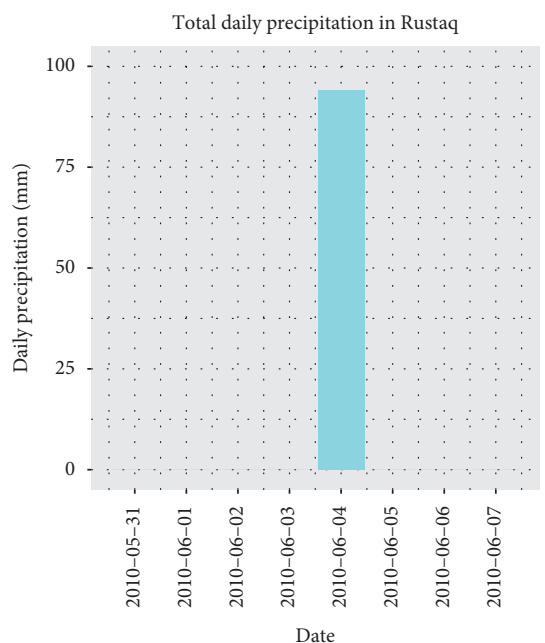

(C)

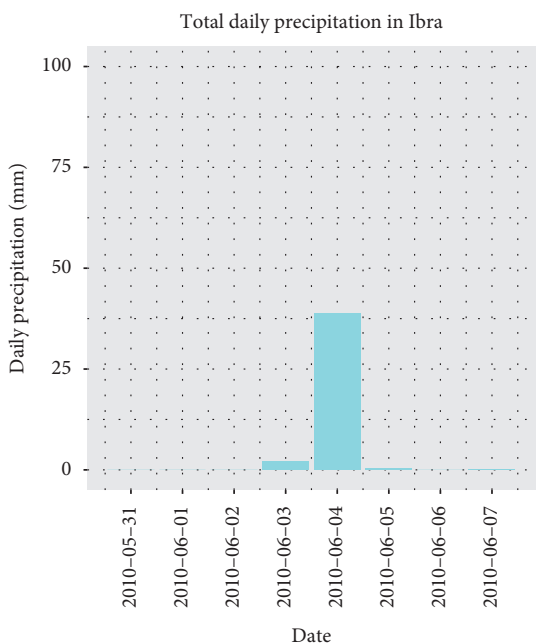

(E)

(c)

Figure 11: Continued. 


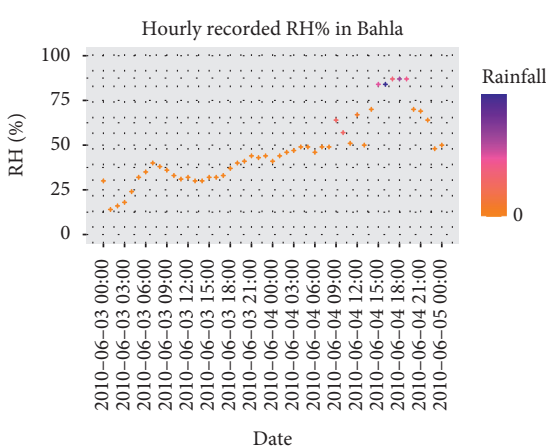

(A)

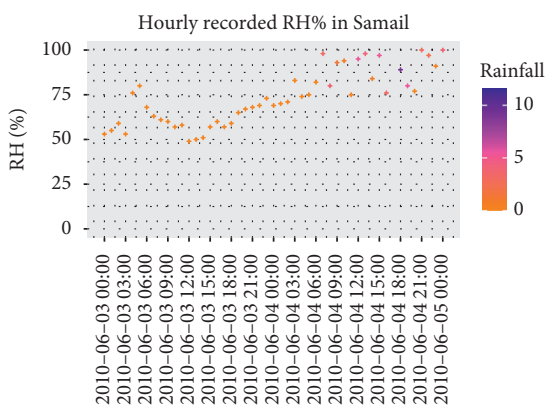

Date

(D)

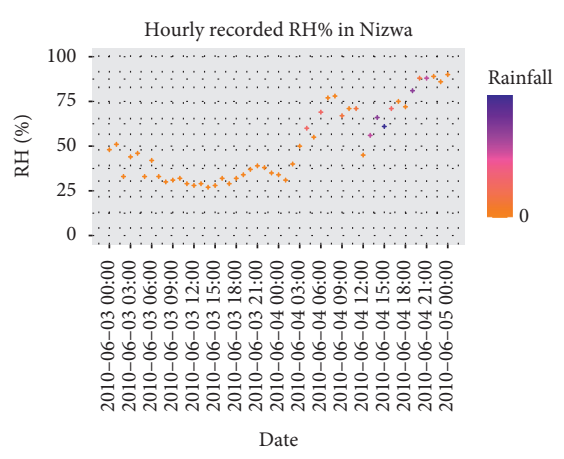

(B)

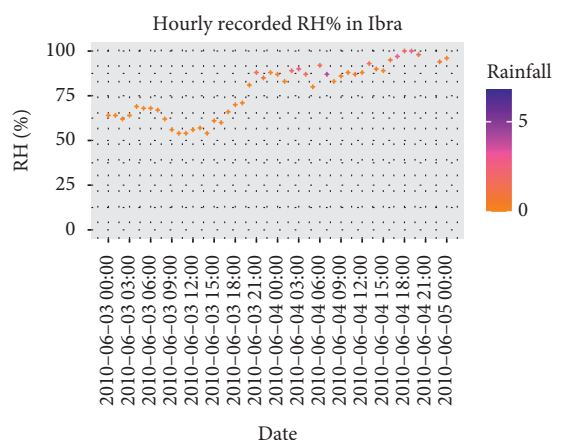

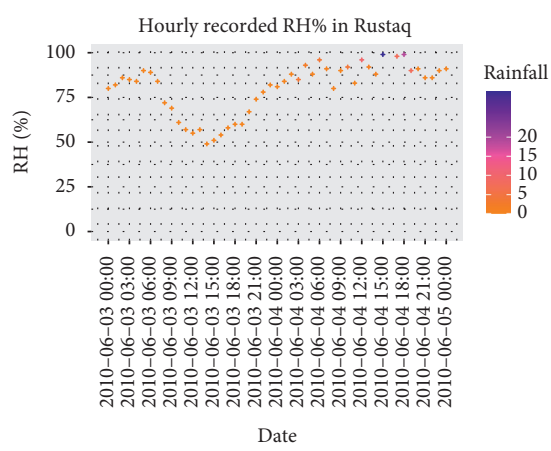

(C)

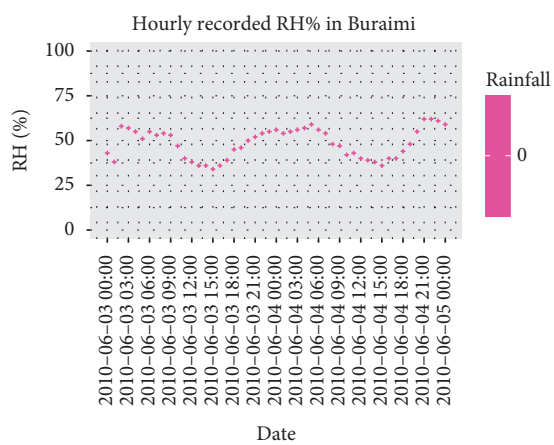

(F)

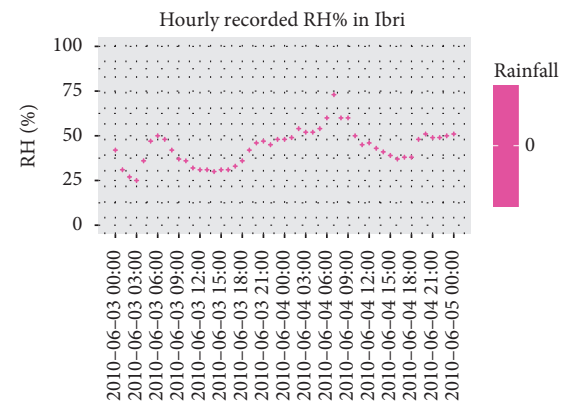

Date

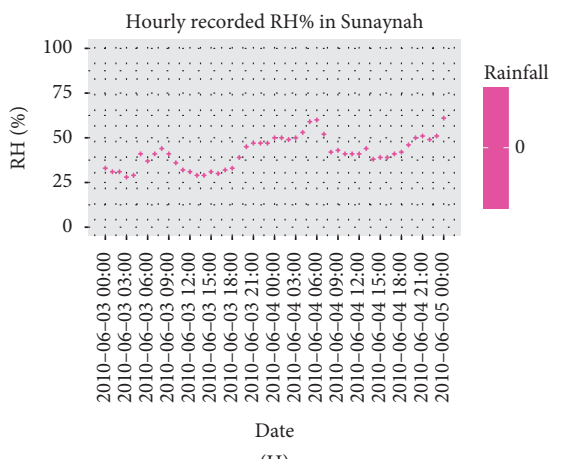

(H)

(d)

FIgURE 11: (a) Hourly temperature variation in ${ }^{\circ} \mathrm{C}$ with respect to the wind direction at some weather stations on the $\mathrm{Al}$-Hajar Mountains during TC "Phet." (b) Hourly precipitation (mm) at some weather stations on the Al-Hajar Mountains during TC "Gonu." (c) Daily precipitation (mm) at some weather stations on the Al-Hajar Mountains during TC "Phet." (d) Hourly RH\% variation with respect to the wind direction at some weather stations on the Al-Hajar Mountains during TC "Phet."

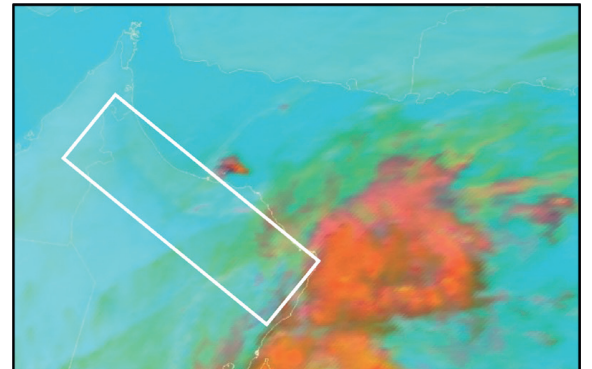

2007-06-03 07:00 UTC

(a)

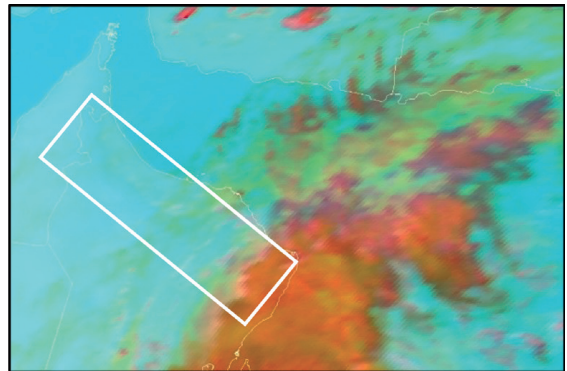

2007-06-03 10:00 UTC

(b)

FIgURE 12: Continued. 


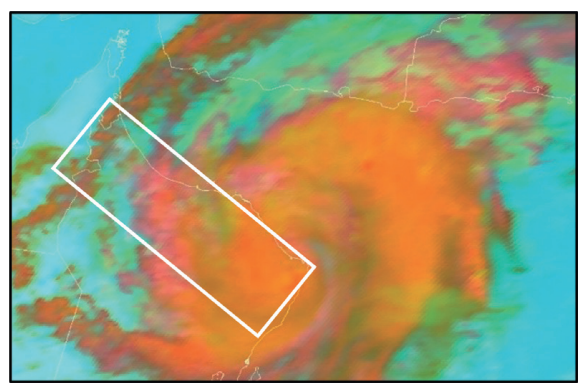

2007-06-04 07:00 UTC

(c)

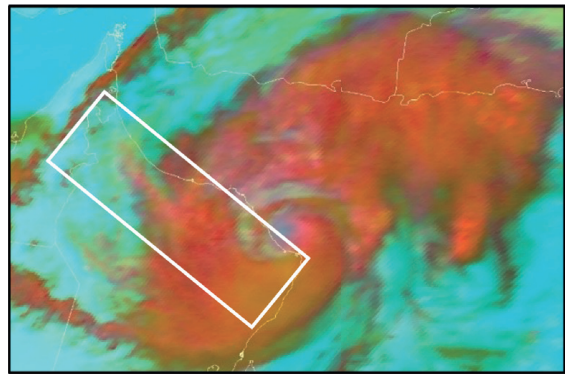

2007-06-04 10:00 UTC

(d)

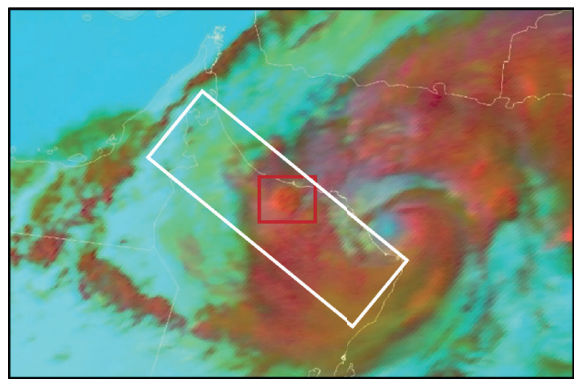

2007-06-04 11:00 UTC

(e)

FIGURE 12: Sequence of day microphysics RGB images on 3 and 4 June 2010. The color scheme is useful to detect optically thick clouds with small ice particles on top (orange), thin clouds with small ice particles (light green), stratocumulus (violet), and water clouds (yellow/green).

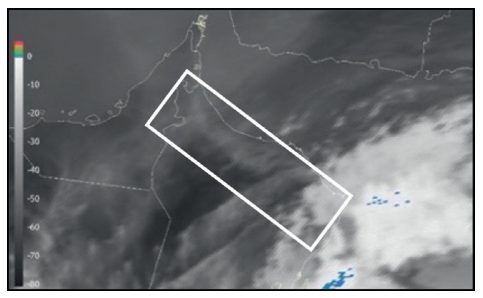

2010-06-03 06:00 UTC

(a)

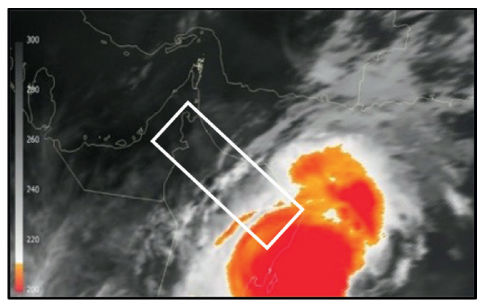

2010-06-03 18:00 UTC

(d)

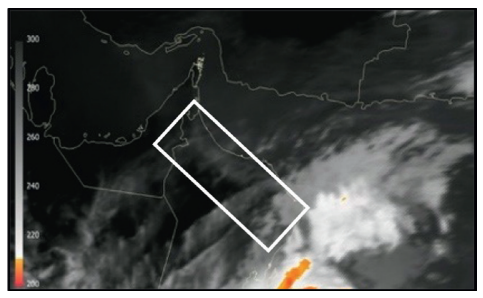

2010-06-03 06:00 UTC

(b)

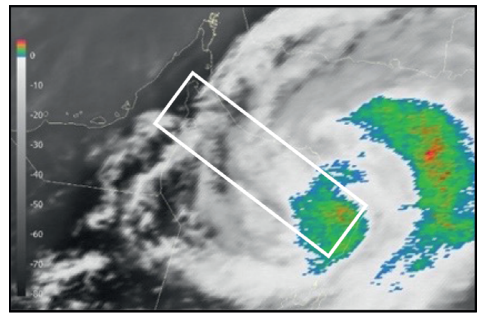

2010-06-04 06:00 UTC

(e)

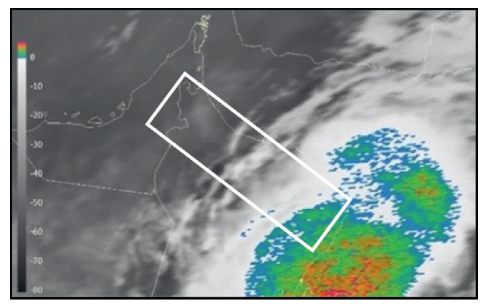

2010-06-03 18:00 UTC

(c)

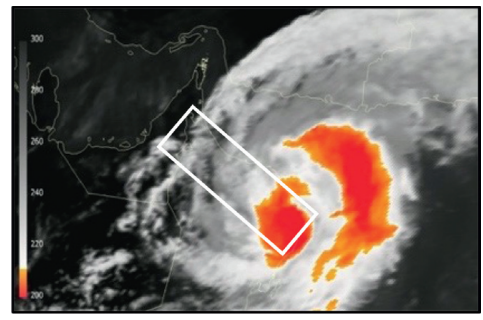

2010-06-04 06:00 UTC

(f)

Figure 13: Continued. 


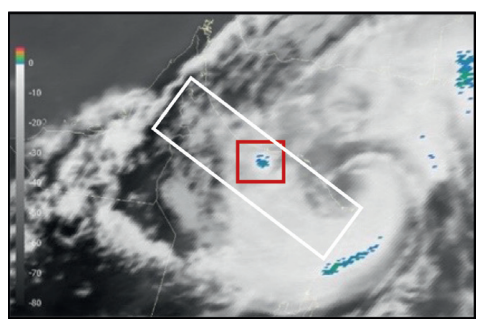

2010-06-04 11:00 UTC

(g)

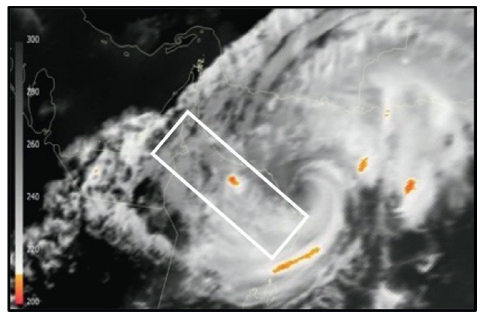

2010-06-04 12:00 UTC

(j)

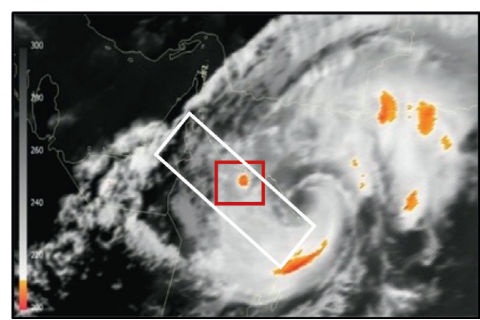

2010-06-04 11:00 UTC

(h)

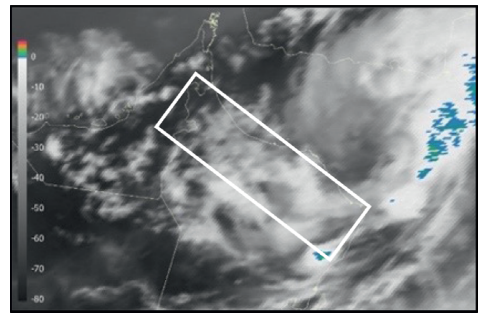

2010-06-04 18:00 UTC

(k)

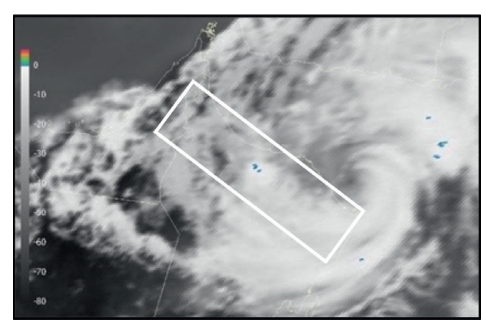

2010-06-04 12:00 UTC

(i)

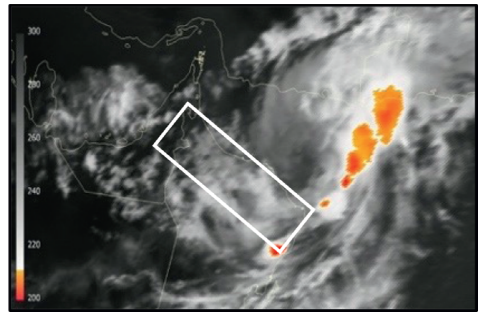

2010-06-04 18:00 UTC

(1)

FIGURE 13: Sequence of BTD (WV6.2 $\mu \mathrm{m}$-IR10.8 $\mu \mathrm{m}$ ) (right) and coldest brightness temperature IR10.8 $\mu \mathrm{m}$ (left) on 3rd and 4th June.

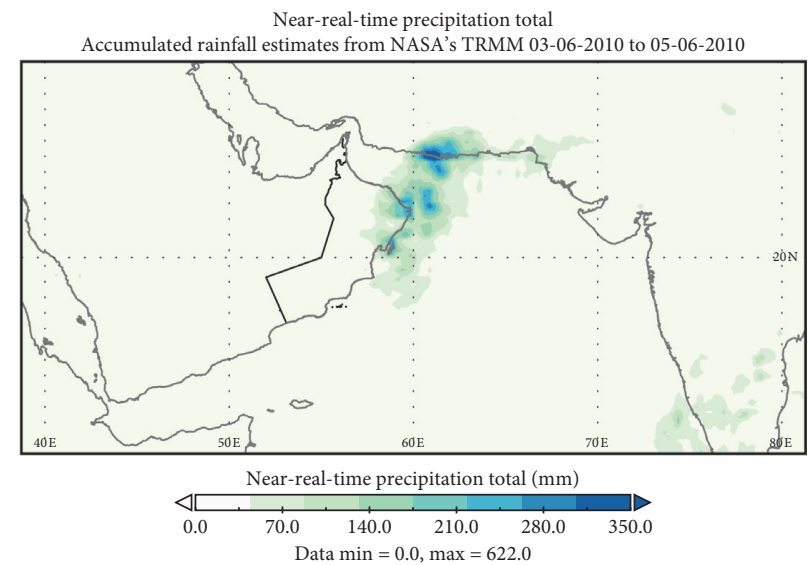

FIgURE 14: Near real-time daily accumulated rainfall estimates from NASA's TRMM satellite for three days (3-5 June 2010).

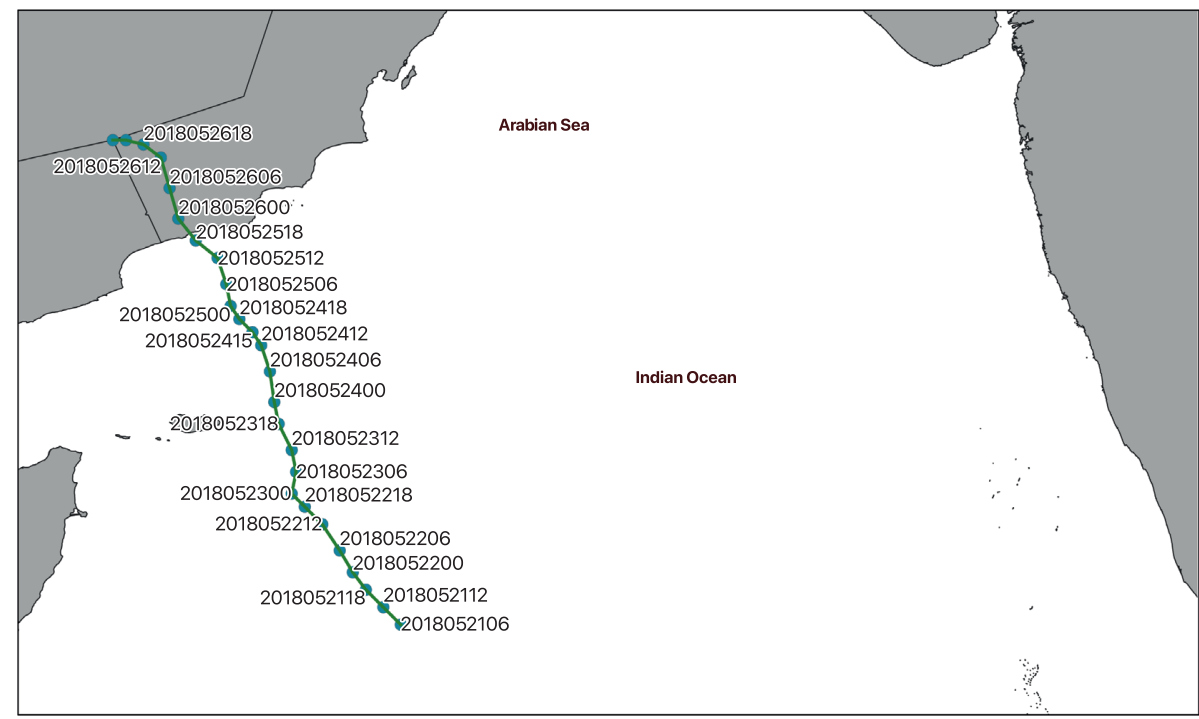

FIgURE 15: The best track of the TC "Mekunu" (source: JTWC). 


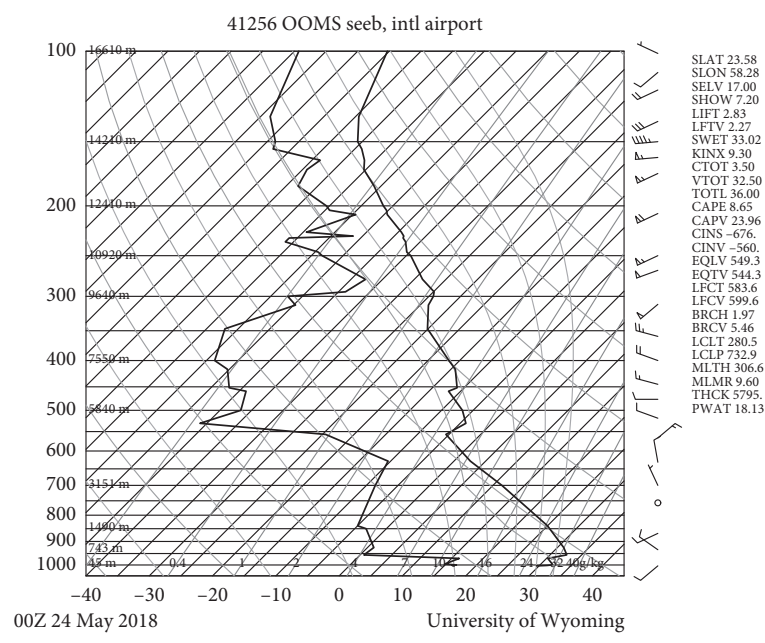

(a)

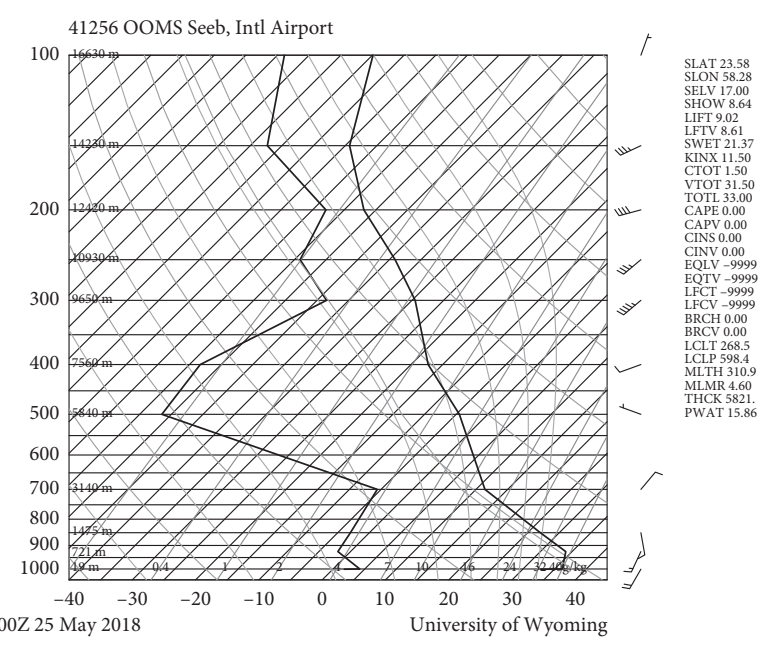

(b)

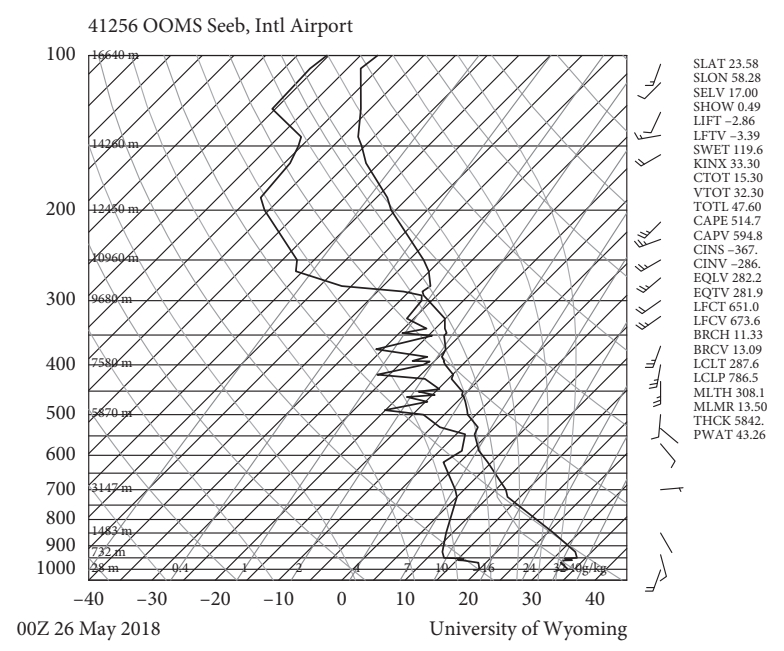

(c)

FIGURE 16: The upper air sounding on (a) 24th of May 2018, (b) 25th of May 2018, and (c) 26th of May 2018 (source: University of Wyoming, 2018).

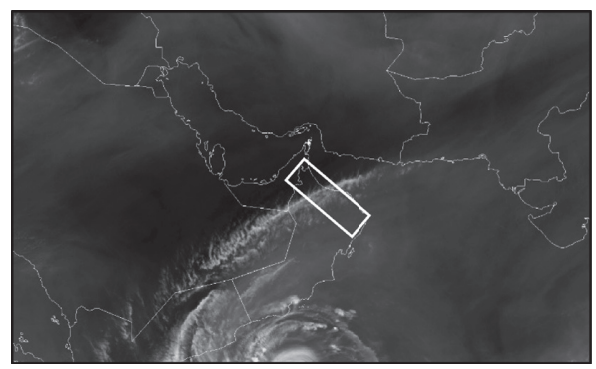

2018-05-24 06:00 UTC

(a)

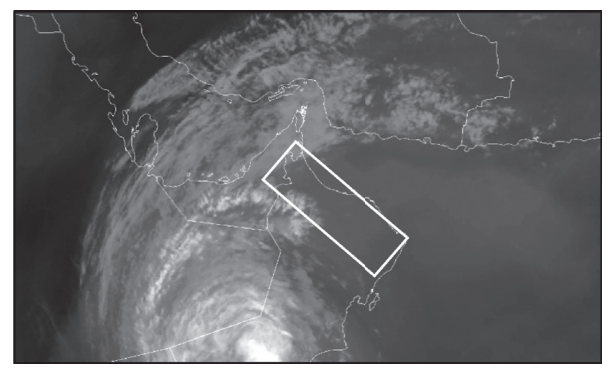

2018-05-26 06:00 UTC

(b)

Figure 17: WV7.3 $\mu \mathrm{m}$ images for (a) 24 May 2018 0600UTC and (b) 26 May 2018 0600UTC.

color in Figure 22. The impact of the TC started on 24 May with the advection of thin cirrus clouds with small ice particle (green in DCMP RGB) (Figure 21(a)). As the TC intensified on the 25th of May, the cirrus clouds appeared into different colors in the DCMP: "green" for small ice thin cirrus cloud and "dark brown" for large ice thin cirrus (Figure 21(c)) and then waned on day 26 with the dissipation of the TC. 


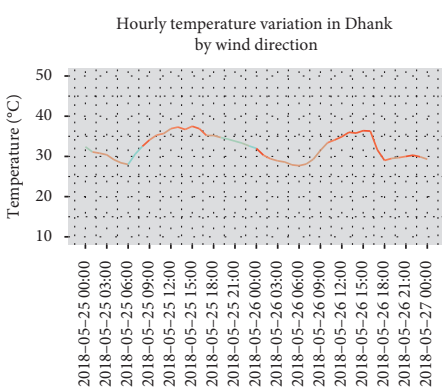

Date

Hourly temperature variation in Samail by wind direction

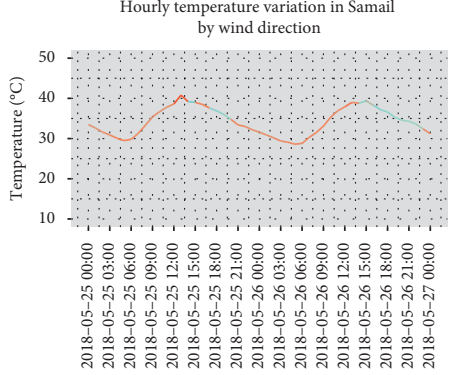

Date

Hourly temperature variation in Ibri by wind direction

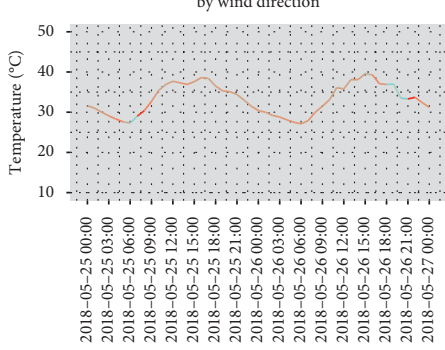

Date

(g)
Hourly temperature variation in Izki by wind direction

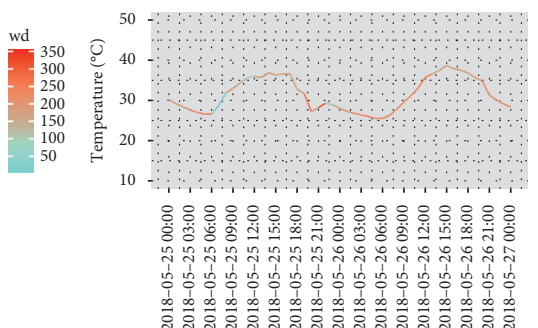

Date

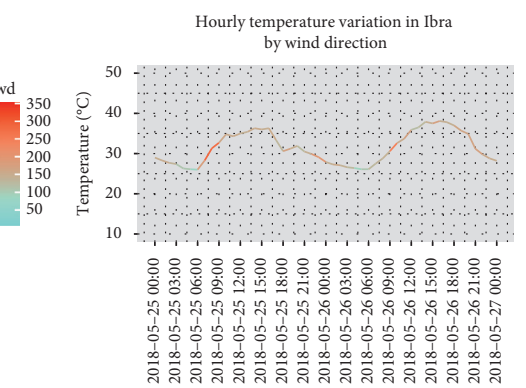

Date

(e)

Hourly temperature variation in Sunaynah by wind direction

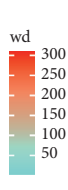

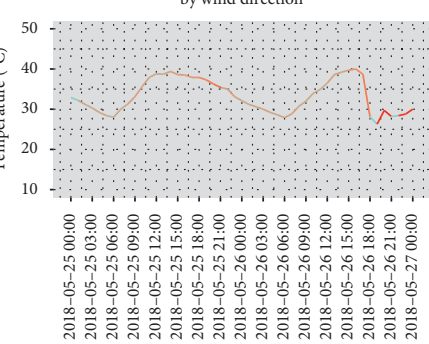

Date

(h)

(a)

Figure 18: Continued.
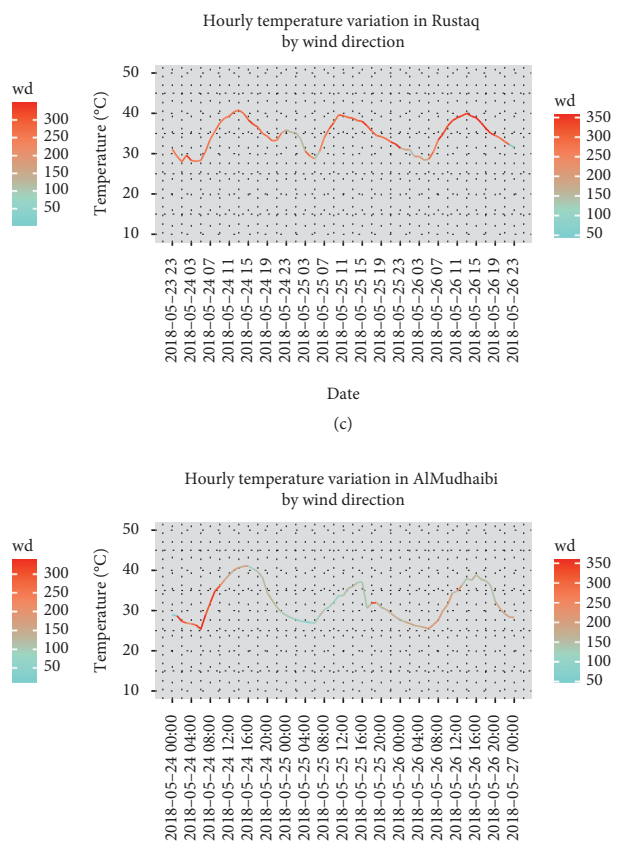

Date

(f)

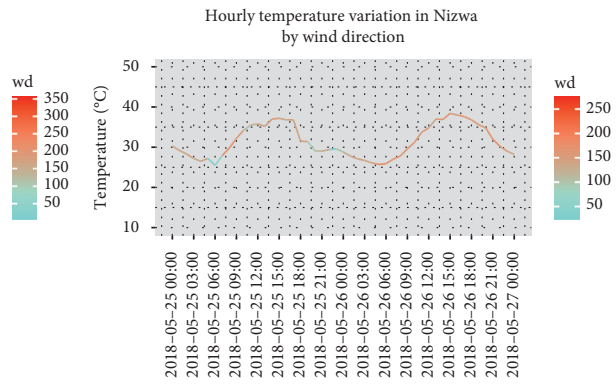

Date

(i) 


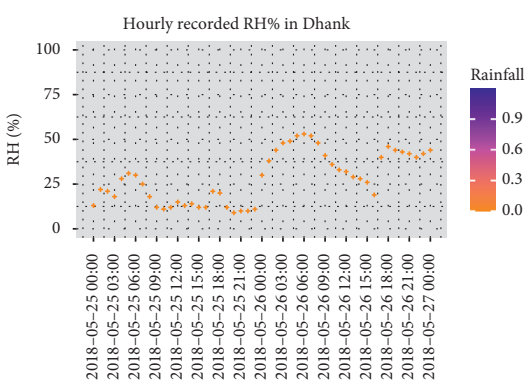

Date

(a)

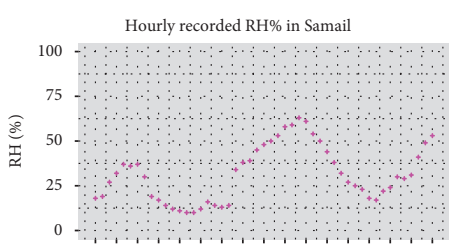

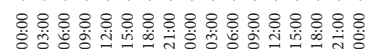

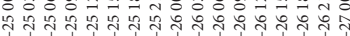

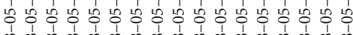

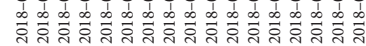

Date

(d)

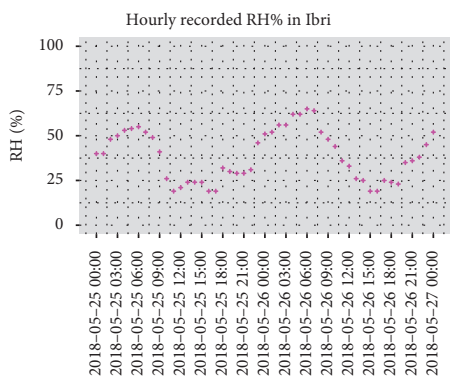

Date

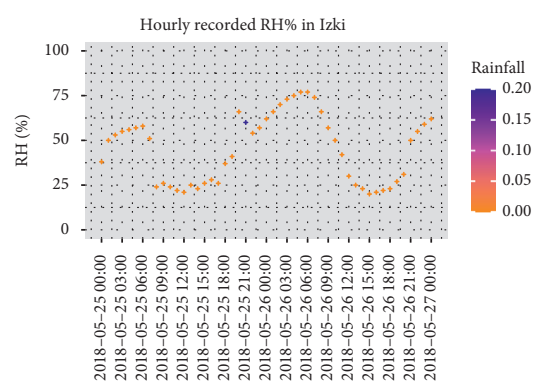

Date

(b)

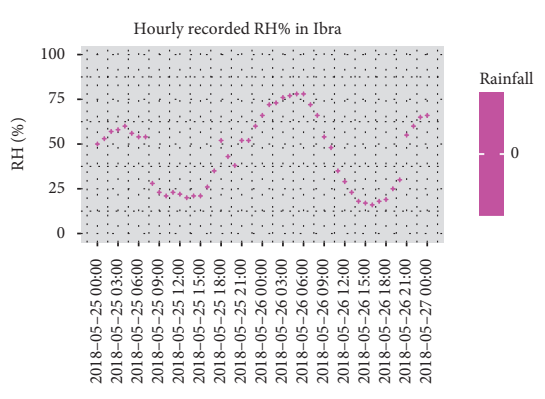

Date

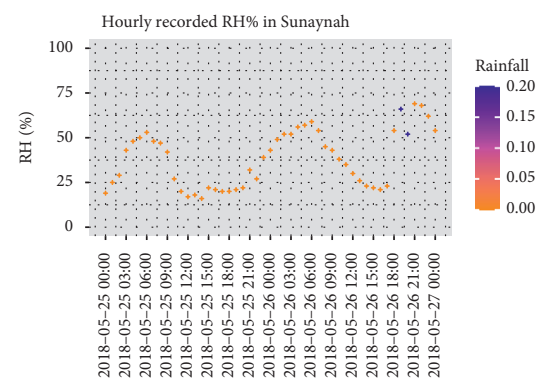

Date

(h)

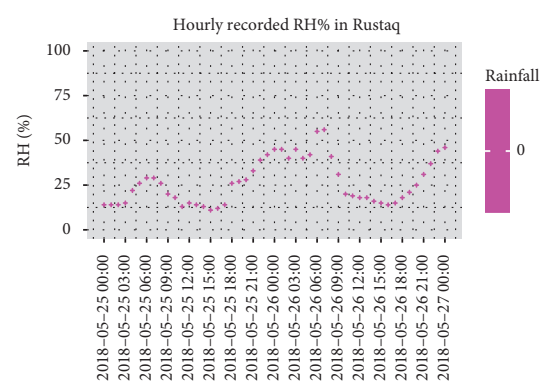

Date

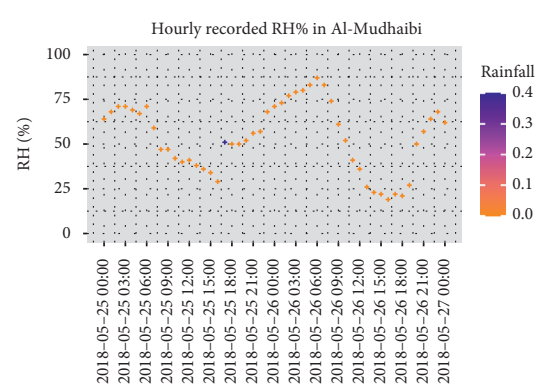

Date

(f)

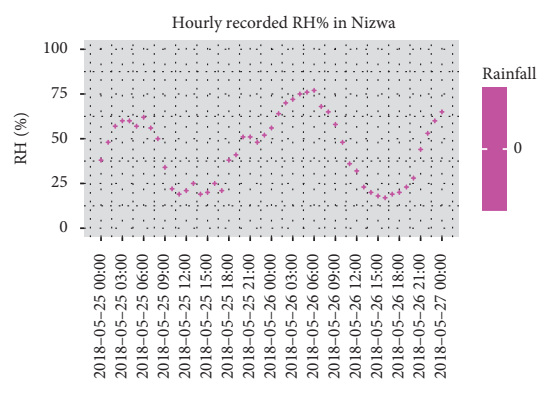

Date

(b)

FIgURE 18: (a) Hourly temperature variation in ${ }^{\circ} \mathrm{C}$ with respect to the wind direction at some weather stations on the Al-Hajar Mountains during TC "Mekunu." (b) Hourly RH\% variation with respect to the wind direction at some weather stations on the Al-Hajar Mountains during TC "Mekunu."

Near-real-time precipitation total

Accumulated rainfall estimates from NASA's TRMM 24-05-2018 to 26-05-2018

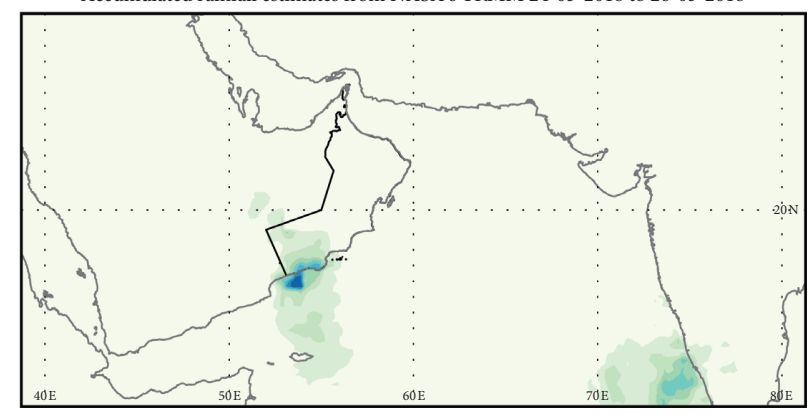

Near-real-time precipitation total $(\mathrm{mm})$

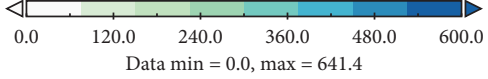

FIgURe 19: Accumulated rainfall estimates from NASA's TRMM satellite for 3 days (24-26 May 2018). 


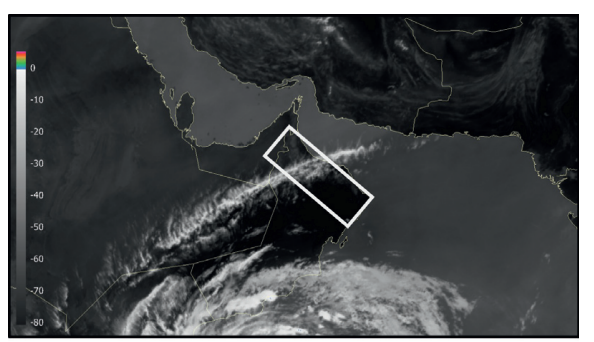

2018-05-24 06:00 UTC

(a)

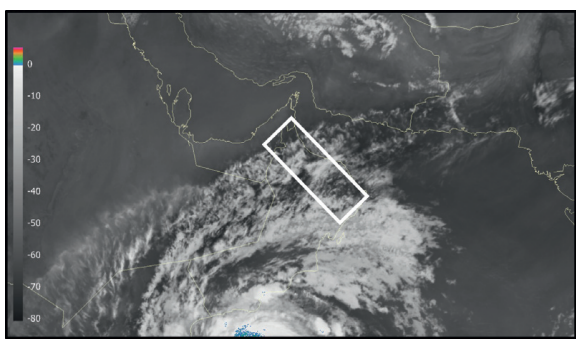

2018-05-24 18:00 UTC

(c)

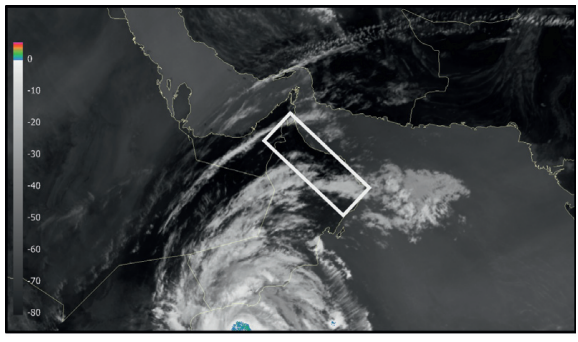

2018-05-25 06:00 UTC

(e)

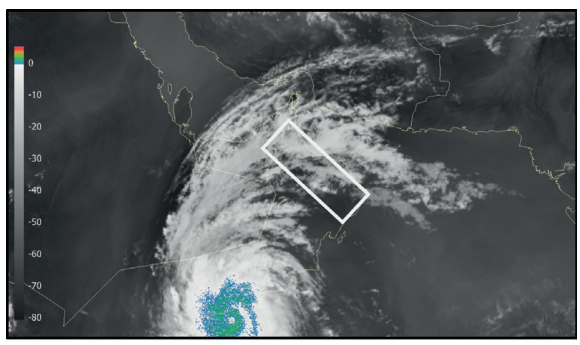

2018-05-25 14:00 UTC

(g)

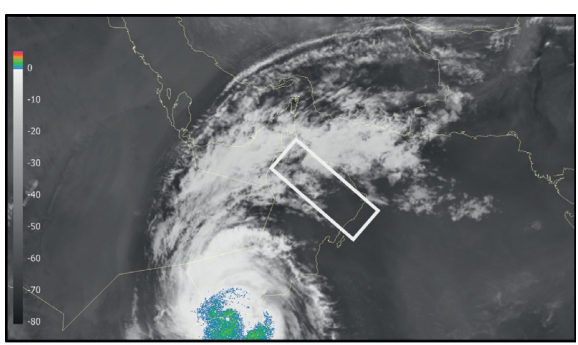

2018-05-25 18:00 UTC

(i)

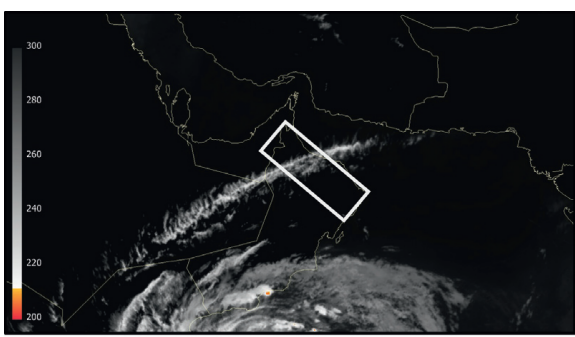

2018-05-24 06:00 UTC

(b)

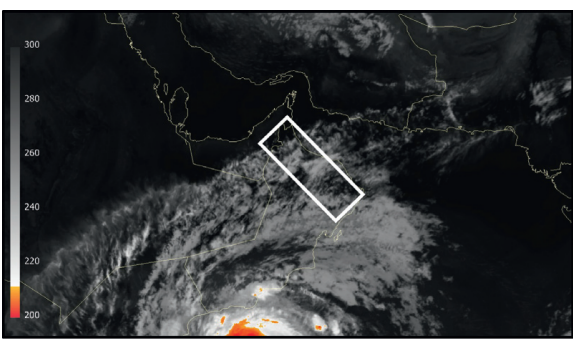

2018-05-24 18:00 UTC

(d)

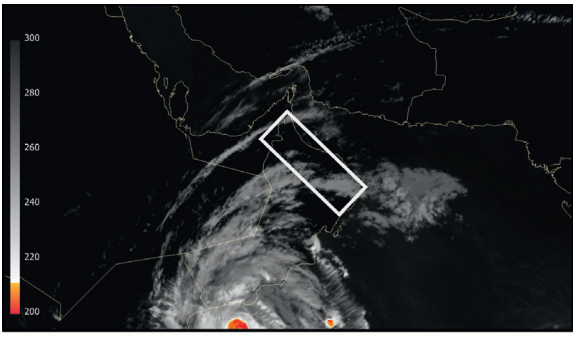

2018-05-25 06:00 UTC

(f)

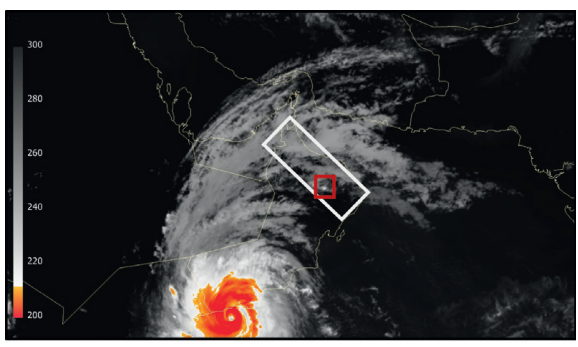

2018-05-25 14:00 UTC

(h)

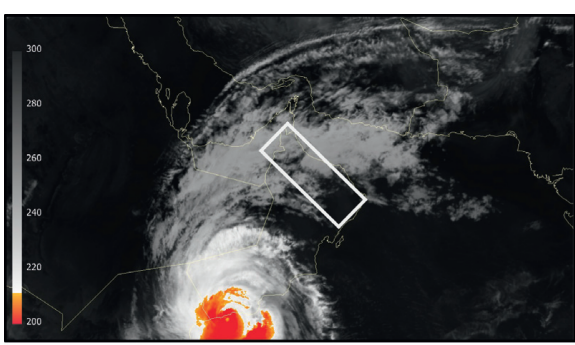

2018-05-25 18:00 UTC

(j)

FIGURE 20: Sequence of BTD (WV6.2 $\mu \mathrm{m}$-IR10.8 $\mu \mathrm{m}$ ) images (right) and coldest brightness temperature IR10.8 $\mu \mathrm{m}$ (left) on 24 and 25 May 2018. 


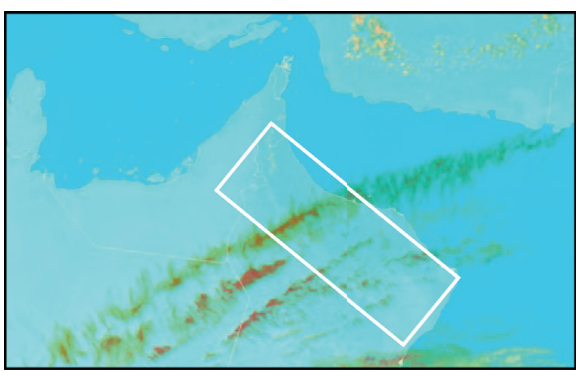

2018-05-24 10:00 UTC

(a)

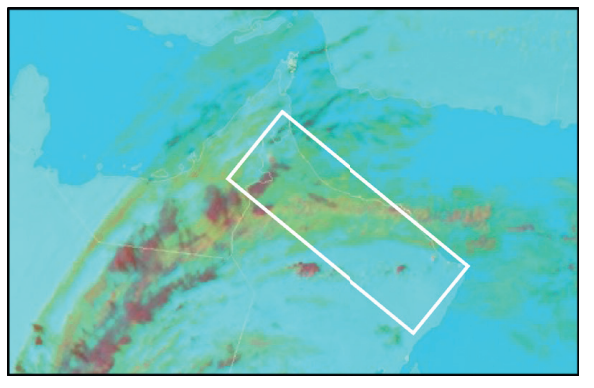

2018-05-25 11:00 UTC

(c)

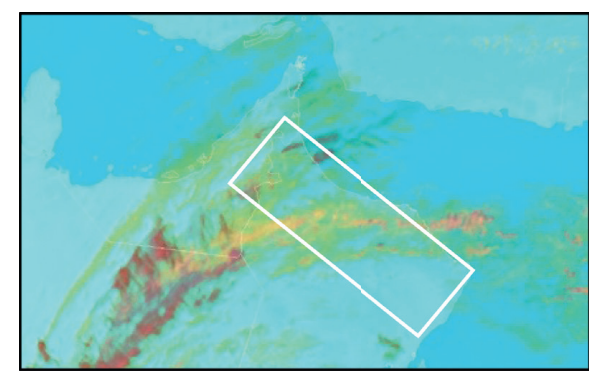

2018-05-25 10:00 UTC

(b)

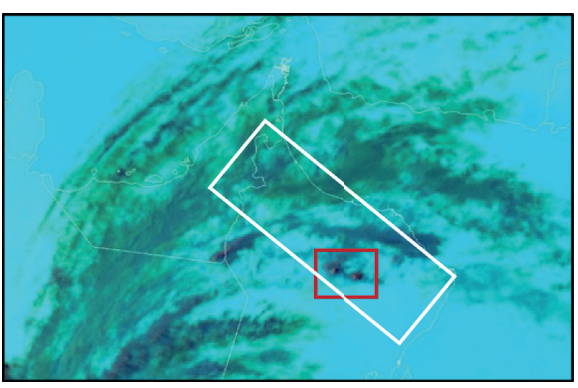

2018-05-25 14:00 UTC

(d)

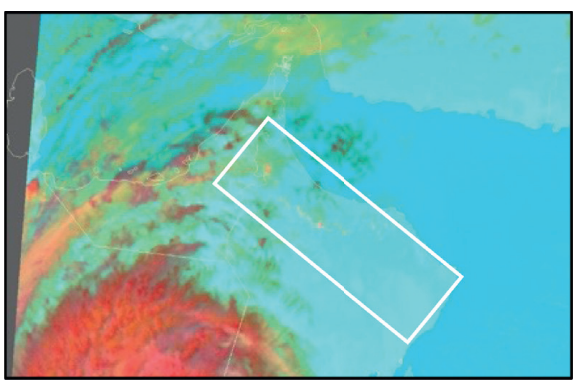

2018-05-26 10:00 UTC

(e)

FIGURE 21: Sequence of day microphysics RGB images on 24 to 26 May 2018. The color scheme is useful to detect optically thick clouds with small ice particles on top (orange), thin clouds with small ice particles (light green), stratocumulus (violet), and water clouds (yellow and green).

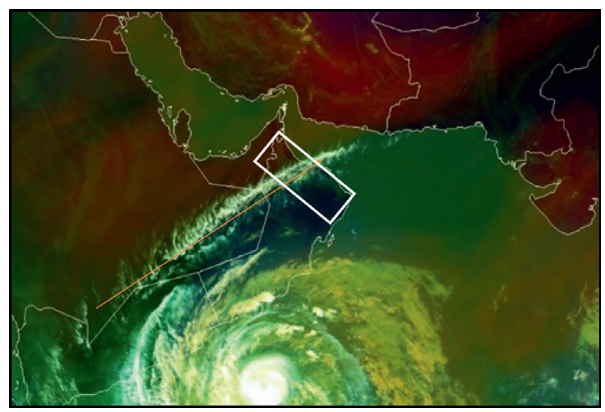

2018 05- 06:00 UTC

FIgURE 22: Airmass RGB (red: $6.2 \mu \mathrm{m}-7.3 \mu \mathrm{m}$; green: $9.7 \mu \mathrm{m}-10.7 \mu \mathrm{m}$; blue: $6.7 \mu \mathrm{m}$ ) on 24 May 0600UTC. 
In contrast to "Gonu" and "Phet" whose track was toward north Oman, Mekunu made landfall in the south of Oman (southwest of Salalah). As, the Al-Hajar Mountains were away from the direct affect of Mekunu, the convection activity over the Al-Hajar Mountains was also weak during the cyclone.

\section{Conclusion}

This study investigated the impact of the tropical cyclones during the premonsoon on the local convection over the AlHajar Mountains by considering the three most significant TCs that both directly (Phet and Mekunu) and indirectly (Gonu) influenced Oman. Data from multiple stations at the Al-Hajar Mountains were used in this study to analyze the prevailing weather conditions $24 \mathrm{hrs}$ before the approach and during the direct effect of the system. The dominant precipitation over the Al-Hajar Mountains during the TCs "Gonu" and "Phet" was from the stratiform clouds. Although some of the weather stations attained the convective temperatures, the heat conduction within the TCs to higher levels during the rapid intensification contributed to the weak environmental lapse rate. Besides, there existed dryness and detrainment of the water vapor at these levels. Moreover, the strengthening of radial outflow from the inner core of the tropical system could suppress the convective updraft as the TC intensifies more.

The limitation of the present study is that installation of the radar network in the county was late, and there are missing archived data. Hence, in future, more studies are required to clearly understand the associated type of precipitation with the TCs in the Arabian Sea and the Indian Ocean. Notwithstanding this limitation, the observations clearly demonstrated the impact of TCs on local convection over the Al-Hajar Mountains in Oman.

This research finding supports the hypothesis that TCs would suppress the development of local convection in the Al-Hajar Mountains. The present results, be of value, can be used as an essential guidance for policy and decision-makers in mapping the risk assessments of the vulnerable areas from such kinds of hazards. Furthermore, this research serves as a baseline for future research in contingency planning and risk reduction.

In addition, the results of this research will help to clarify the misconception of convection prediction during the critical time of the TCs in the Arabian Sea, which would be falsely predicted to be deeper in the Al-Hajar Mountains with the advancement of the TCs, and that is not the case here.

\section{Data Availability}

The data used to support the findings of this study are included within the article.

\section{Conflicts of Interest}

The authors declare that they have no conflicts of interest.

\section{Acknowledgments}

The authors would like to thank Dr. Khalid Al-Habsi, Professor Liesl Dyson, and Professor Peter Sammonds for reviewing the article and providing constructive critiques and valuable comments. Extended thanks go to the Research and Development Department at DGMET for providing them with the required data.

\section{References}

[1] C. Blount, H. M. Fritz, F. B. Albusaidi, and A. H. Al-Harthy, "Storm surge hazard in Oman based on cyclone Gonu and historic events," in Proceedings of the Fall Meeting 2008, San Francisco, CA, USA, December 2008.

[2] India Meteorological Department, "IMD [WWW Document]," 2020, http://www.rsmcnewdelhi.imd.gov.in/.

[3] P. Byju and S. Prasanna Kumar, "Physical and biological response of the Arabian Sea to tropical cyclone Phyan and its implications," Marine Environmental Research, vol. 71, no. 5, pp. 325-330, 2011.

[4] Z. Wang, S. F. DiMarco, M. M. Stössel, X. Zhang, M. K. Howard, and K. Du Vall, "Oscillation responses to tropical cyclone Gonu in Northern Arabian Sea from a moored observing system," Deep Sea Research Part I: Oceanographic Research Papers, vol. 64, pp. 129-145, 2012.

[5] H. Murakami, G. A. Vecchi, and S. Underwood, "Increasing frequency of extremely severe cyclonic storms over the Arabian Sea," Nature Climate Change, vol. 7, no. 12, pp. 885-889, 2017.

[6] A. T. Evan, J. P. Kossin, C. 'Eddy' Chung, and V. Ramanathan, "Arabian Sea tropical cyclones intensified by emissions of black carbon and other aerosols," Nature, vol. 479, no. 7371, pp. 94-97, 2011.

[7] H. A. S. Al-Brashdi, Forecasting Techniques for Seedable Storms over the Western Hajar Mountains in the Sultanate of Oman, University of Pretoria, Pretoria, South Africa, 2008.

[8] Y. Huang, A. M. Blyth, and P. R. A. Brown, "The physics of clouds in the atmosphere the development of ice in a cumulus cloud over southwest England Notes on state-of-the-art investigations of aerosol effects on precipitation: a criticalreview," Reports on Progress in Physics, vol. 46, 1983.

[9] L. Kolendowicz, M. Taszarek, and B. Czernecki, "Atmospheric circulation and sounding-derived parameters associated with thunderstorm occurrence in Central Europe," Atmospheric Research, vol. 191, pp. 101-114, 2017.

[10] B. S. Murthy and S. Sivaramakrishnan, "Moist convective instability over the Arabian Sea during the Asian summer monsoon, 2002," Meteorological Applications, vol. 13, no. 1, pp. 63-72, 2006.

[11] R. A. Peppler and P. J. Lamb, "Tropospheric static stability and Central North American growing season rainfall," Monthly Weather Review, vol. 117, no. 6, pp. 1156-1180, 1989.

[12] S. Tajbakhsh, P. Ghafarian, and F. Sahraian, "Instability indices and forecasting thunderstorms: the case of 30 April 2009," Natural Hazards and Earth System Sciences, vol. 12, no. 2, pp. 403-413, 2012.

[13] S. Al-Zadjali, Performance of Oman Convective Index (OCI) in Forcasting Summer Storms over Al-Hajar Mountains in Oman, University of Birmingham, Birmingham, England, 2017.

[14] J. P. Duvel, "Convection over tropical africa and the atlantic ocean during northern summer. Part I: interannual and diurnal variations," Monthly Weather Review, vol. 117, no. 12, pp. 2782-2799, 1989. 
[15] D. A. Vondou, "Spatio-temporal variability of western central african convection from infrared observations," Atmosphere, vol. 3, no. 3, pp. 377-399, 2012.

[16] J. Al-Maskari, A. Gadian, and P. Smolarkiewicz, A Study of Orographic Convection over the Hajar Mountains in Northern Oman, University of Leeds, Leeds, UK, 2006.

[17] D. Fleitmann, S. J. Burns, M. Mudelsee et al., "Holocene ITCZ migration recorded in stalagmites from Southern Oman," in Proceedings of the Fall Meeting 2002, Santa Fe, NM, USA, August 2002.

[18] Y.-L. Lin, D. B. Ensley, S. Chiao, and C. Y. Huang, "Orographic influences on rainfall and track deflection associated with the passage of a tropical cyclone," Monthly Weather Review, vol. 130, no. 12, pp. 2929-2950, 2002.

[19] D. Halpern and P. M. Woiceshyn, "Onset of the Somali jet in the Arabian sea during June 1997," Journal of Geophysical Research: Oceans, vol. 104, no. C8, pp. 18041-18046, 1999.

[20] R. E. Eager, S. Raman, A. Wootten, D. L. Westphal, J. S. Reid, and A. Al-Mandoos, "A climatological study of the sea and land breezes in the Arabian Gulf region," Journal of Geophysical Research, vol. 113, no. D15, 2008.

[21] G. J. Huffman, D. T. Bolvin, E. J. Nelkin, and R. F. Adler, TRMM (TMPA) Precipitation L3 1 day 0.25 degree $x 0.25$ degree V7, A. Savtchenko, Ed., Goddard Earth Sciences Data and Information Services Center (GES DISC), Greenbelt, MD, USA, 2016.

[22] M. O. Andreae and D. Rosenfeld, “Aerosol-cloud-precipitation interactions. Part 1. The nature and sources of cloud-active aerosols," Earth-Science Reviews, vol. 89, no. 1-2, pp. 13-41, 2008.

[23] S. Fritz and I. Laszlo, "Detection of water vapor in the stratosphere over very high clouds in the tropics," Journal of Geophysical Research, vol. 98, no. D12, pp. 22959-22967, 1993.

[24] R. A. Houze, "Nimbostratus and the separation of convective and stratiform precipitation," International Geophysics, vol. 104, pp. 141-163, 2014.

[25] C. Schumacher and R. A. Houze, "Stratiform rain in the tropics as seen by the TRMM precipitation radar," Journal of Climate, vol. 16, no. 11, pp. 1739-1756, 2003.

[26] RSMC-Tropical Cyclone, Report on Cyclonic Disturbances over the North Indian Ocean during 2010, RSMC, New Delhi, India, 2011.

[27] Z. Yang, T. Yuan, H. Jiang, L. Zhang, and C. Zhang, "Stratiform and convective precipitation properties of tropical cyclones in the Northwest Pacific," Journal of Geophysical Research: Atmospheres, vol. 123, no. 7, pp. 3513-3529, 2018.

[28] S. J. Böing, H. J. J. Jonker, A. P. Siebesma, and W. W. Grabowski, "Influence of the subcloud layer on the development of a deep convective ensemble," Journal of the Atmospheric Sciences, vol. 69, no. 9, pp. 2682-2698, 2012.

[29] Z. Feng, S. Hagos, A. K. Rowe, C. D. Burleyson, M. N. Martini, and S. P. Szoeke, "Mechanisms of convective cloud organization by cold pools over tropical warm ocean during the AMIE/DYNAMO field campaign," Journal of Advances in Modeling Earth Systems, vol. 7, no. 2, pp. 357-381, 2015.

[30] T. Fuyi, M. Z. MatJafri, H.-S. Lim, and K. Abdullah, "The effects of orography on cloud and rainfall patterns during typhoon Ketsana (2009)," in Proceedings of the Earth Resources and Environmental Remote Sensing/GIS Applications III, U. Michel, D. L. Civco, M. Ehlers et al., Eds., vol. 8538, p. 853819, International Society for Optics and Photonics, Bellingham, Washington, USA, 2012.
[31] T. Takemi, "Dependence of the precipitation intensity in mesoscale convective systems to temperature lapse rate," Atmospheric Research, vol. 96, no. 2-3, pp. 273-285, 2010.

[32] A. M. Tompkins, "Organization of tropical convection in low vertical wind shears: the role of water vapor," Journal of the Atmospheric Sciences, vol. 58, no. 6, pp. 529-545, 2001. 